\title{
Transactions
}

Cite this: Dalton Trans., 2011, 40,6420

wWW.rsc.org/dalton

PAPER

\section{Reactivity, photolability, and computational studies of the ruthenium nitrosyl complex with a substituted cyclam $f a c-\left[\mathrm{Ru}(\mathrm{NO}) \mathrm{Cl}_{2}\left(\kappa^{3} \mathrm{~N}^{4}, \mathrm{~N}^{8}, \mathrm{~N}^{11}(1-\right.\right.$ carboxypropyl)cyclam) $] \mathrm{Cl} \cdot \mathrm{H}_{2} \mathrm{O} \uparrow$}

\author{
Fabio G. Doro, ${ }^{a, d}$ Iuri M. Pepe, ${ }^{b}$ Sergio E. Galembeck, ${ }^{a}$ Rose M. Carlos, ${ }^{c}$ Zenis N. da Rocha, ${ }^{d}$ Mauro Bertotti ${ }^{e}$ \\ and Elia Tfouni*a
}

Received 5th November 2010, Accepted 4th April 2011

DOI: $10.1039 /$ c0dt01541e

Chemical reactivity, photolability, and computational studies of the ruthenium nitrosyl complex with a substituted cyclam, fac-[Ru(NO) $\mathrm{Cl}_{2}\left(\kappa^{3} \mathrm{~N}^{4}, \mathrm{~N}^{8}, \mathrm{~N}^{11}(1\right.$-carboxypropyl)cyclam) $] \mathrm{Cl} \cdot \mathrm{H}_{2} \mathrm{O}$ ((1-carboxypropyl)cyclam = 3-(1,4,8,11-tetraazacyclotetradecan-1-yl)propionic acid)), (I) are described. Chloride ligands do not undergo aquation reactions (at $25^{\circ} \mathrm{C}, \mathrm{pH} 3$ ). The rate of nitric oxide (NO) dissociation $\left(k_{o b s-\mathrm{NO}}\right)$ upon reduction of $\mathbf{I}$ is $2.8 \mathrm{~s}^{-1}$ at $25 \pm 1{ }^{\circ} \mathrm{C}$ (in $0.5 \mathrm{~mol} \mathrm{~L} \mathrm{~L}^{-1} \mathrm{HCl}$ ), which is close to the highest value found for related complexes. The uncoordinated carboxyl of $\mathbf{I}$ has a $\mathrm{p} K_{\mathrm{a}}$ of $\sim 3.3$, which is close to that of the carboxyl of the non coordinated (1-carboxypropyl)cyclam $\left(\mathrm{p} K_{\mathrm{a}}=3.4\right)$. Two additional $\mathrm{p} K_{\mathrm{a}}$ values were found for $\mathbf{I}$ at $\sim 8.0$ and $\sim 11.5$. Upon electrochemical reduction or under irradiation with light $\left(\lambda_{\text {irr }}=350\right.$ or $\left.520 \mathrm{~nm} ; \mathrm{pH} 7.4\right)$, I releases NO in aqueous solution. The cyclam ring $\mathrm{N}$ bound to the carboxypropyl group is not coordinated, resulting in a fac configuration that affects the properties and chemical reactivities of $\mathbf{I}$, especially as NO donor, compared with analogous trans complexes. Among the computational models tested, the B3LYP/ECP28MDF, cc-pVDZ resulted in smaller errors for the geometry of $\mathbf{I}$. The computational data helped clarify the experimental acid-base equilibria and indicated the most favourable site for the second deprotonation, which follows that of the carboxyl group. Furthermore, it showed that by changing the $\mathrm{pH}$ it is possible to modulate the electron density of I with deprotonation. The calculated $\mathrm{NO}$ bond length and the Ru/NO charge ratio indicated that the predominant canonical structure is $\left[\mathrm{Ru}^{\mathrm{III}} \mathrm{NO}\right]$, but the $\mathrm{Ru}-\mathrm{NO}$ bond angles and bond index (b.i.) values were less clear; the angles suggested that $\left[\mathrm{Ru}^{\mathrm{II}} \mathrm{NO}^{+}\right]$could contribute to the electronic structure of $\mathbf{I}$ and b.i. values indicated a contribution from $\left[\mathrm{Ru}^{\mathrm{IV}} \mathrm{NO}^{-}\right]$. Considering that some experimental data are consistent with a $\left[\mathrm{Ru}^{\mathrm{II}} \mathrm{NO}^{+}\right]$description, while others are in agreement with $\left[\mathrm{Ru}^{\mathrm{III}} \mathrm{NO}\right]$, the best description for $\mathbf{I}$ would be a linear combination of the three canonical forms, with a higher weight for $\left[\mathrm{Ru}^{\mathrm{II}} \mathrm{NO}^{+}\right]$and $\left[\mathrm{Ru}^{\mathrm{III}} \mathrm{NO}\right]$.

\section{Introduction}

Efforts from our Laboratory have been directed towards the design and study of ruthenium nitrosyl complexes as nitric oxide

${ }^{a}$ Departamento de Química, Faculdade de Filosofia, Ciências e Letras de Ribeirão Preto. Universidade de São Paulo, Av. dos Bandeirantes 3900, 14040-901, Ribeirão Preto, SP, Brazil.E-mail: eltfouni@usp.br; Fax: +5516-3602-4838; Tel: +55-16-3602-3748

${ }^{b}$ Optical Properties Laboratory, LaPO, Instituto de Física, Universidade Federal da Bahia, Salvador, BA, Brazil

'Departamento de Química, Universidade Federal de São Carlos, CP 676, 13565-905, São Carlos, SP, Brazil

'Instituto de Química, Universidade Federal da Bahia, Campus Ondina, 40170-290, Salvador, BA, Brazil

'Instituto de Química, Universidade de São Paulo, av. Prof. Lineu Prestes, n. 748, Cidade Universitária, 05508-900, São Paulo, SP, Brazil

$\dagger$ Electronic supplementary information (ESI) available: See DOI: $10.1039 / \mathrm{c} 0 \mathrm{dt} 01541 \mathrm{e}$
(NO) donors, aiming at biological applications in solution or in matrices. ${ }^{1-4}$ Complexes with the equatorial positions occupied by four ammines or aliphatic tetraazamacrocycle ligands, such as cyclam (1,4,8,11-tetraazacyclotetradecane) and related species have been studied. ${ }^{1-13}$ Compared with the tetraammines, tetraazamacrocycles impart some differences, such as restriction of substitution reactions to the other ligands because of the inertness of the macrocyle. ${ }^{1,5,9,12,14}$ Significant advances have been achieved in tailoring the NO reactivity for Ru nitrosyl tetraammines, and they have been used as metallopharmaceutical NO pro-drugs ${ }^{4,6,11,15-23}$ In trans-[Ru(NO) $\left.\left(\mathrm{NH}_{3}\right)_{4}(\mathrm{~L})\right]^{n+}$ complexes, the judicious choice of the ligand L trans to NO may allow for control of the $\{\mathrm{RuNO}\}^{6 / 7}$ redox potentials, rates of $\mathrm{NO}$ release $\left(k_{-\mathrm{NO}}\right)$ after reduction, and electrophilicity of the nitrosyl ligand. ${ }^{2,4}$ For instance, $k_{\text {-NO }}$ values for $\mathrm{L}=$ py (pyridine), $\mathrm{P}(\mathrm{OEt})_{3}$ (triethylphosphite) or im $C$ (carbon-bound imidazole) are $0.06,0.98$, and $5.1 \mathrm{~s}^{-1}$, respectively. However, when the four ammonias are replaced by cyclam, as in 
trans-[Ru(NO)Cl(cyclam) $]\left(\mathrm{PF}_{6}\right)_{2}$, the rate of $\mathrm{NO}$ release has been found to be $6.1 \times 10^{-4} \mathrm{~s}^{-1}{ }^{1,2,6}$ Appending functional groups to $\mathrm{N}$ (or C) atoms in the cyclam ring could lead to strategic tuning of the reactivity of tetraazamacrocyclic ruthenium nitrosyl complexes ${ }^{7,8}$ In addition, these functional groups could provide a linking unit to matrices or molecules of biological importance, which selectively target NO release.

Recently, the synthesis and characterisation of the fac$\left[\mathrm{Ru}(\mathrm{NO}) \mathrm{Cl}_{2}\left(\kappa^{3} \mathrm{~N}^{4}, \mathrm{~N}^{8}, \mathrm{~N}^{11}\right.\right.$ (1-carboxypropyl)cyclam) $] \mathrm{Cl} \cdot \mathrm{H}_{2} \mathrm{O}$ complex ((1-carboxypropyl)cyclam = 3-(1,4,8,11-tetraazacyclotetradecan-1-yl)propionic acid) (I) has been reported ${ }^{7}$ (Fig. 1). The fac configuration was observed in contrast to the expected trans arrangement as a result of the $\kappa^{3}$ denticity adopted by the mono-N-substituted 1-(carboxypropyl)cyclam ligand. ${ }^{7}$ The cyclam $\mathrm{N}$ atom that is bound to the carboxypropyl group remained uncoordinated. In its infrared absorption spectrum, this complex displayed a stretching absorption peak, $v(\mathrm{NO})$, at $1881 \mathrm{~cm}^{-1}$ and the $\mathrm{Ru}-\mathrm{N}$ interatomic distance and bond angle for the [RuNO] core of $1.739(2) \AA$ and $167.7(2)^{\circ}$, respectively. Unlike I, a majority of cyclam and related complexes generally adopt a cis or trans configuration with the four cyclam $\mathrm{N}$ atoms coordinated to the metal centre. $1,5,6,8-11,13,14,24-27$ These cis or trans configurations depend on the size of the macrocycle and on the oxidation state of metal, 1,14,25,27 which can greatly influence their chemical properties. ${ }^{1,13,14,25}$ Besides the influences exerted on the configuration of the complexes, macrocycle size and Ru oxidation state have important roles in the reactivity of the complexes. For instance, while $\mathrm{Ru}(\mathrm{III})$ cyclam dichloro complexes are remarkably inert towards ligand substitution, $\mathrm{Ru}(\mathrm{II})$ analogous complexes are relatively labile.,14 The inertness of the chloro ligand of $\mathrm{Ru}(\mathrm{II})$ cyclam complexes compared with the analogous tetraammine complexes has been attributed to intramolecular $\mathrm{Cl} \cdots \mathrm{H}-\mathrm{N}$ interactions. ${ }^{1,5,14}$ Cyclam N-substitution has increased chloride lability by weakening these interactions (mono-N-substitution), as in 1-(3-propylammonium)cyclam, ${ }^{10}$ or by eliminating them (tetrasubstitution), as in 1,4,8,11-tetramethylcylam (14-TMC). ${ }^{1}$

Ruthenium nitrosyl ammine and aliphatic tetraazamacrocycle complexes act as potential NO delivery agents because they release NO upon reduction or under irradiation with light. ${ }^{1,2,8,11,28,29}$ These complexes also have a very rich potential as NO delivery agents in biological systems. ${ }^{4,6,11,15,17-23,28} \mathrm{NO}$ is involved in a remarkably diverse range of physiological and pathophysiological processes. ${ }^{30}$ NO is kown to act as biological messenger responsible for vasodilation, to inhibit platelet aggregation, to play a role in immune response, and to act as a neurotransmitter. ${ }^{30-32}$ Studies have also shown that NO could be involved in cell apoptosis and tumor kills.s.334 Thus, compounds that have the ability to release $\mathrm{NO}$ are of great interest.

Some authors have presented theoretical results for ruthenium nitrosyl complexes. Ford et al. ${ }^{35}$ in a theoretical and experimental work, performed geometrical and vibrational frequencies calculations for dinitrosyl ruthenium porphyrin complexes. The calculations allowed the most stable conformation to be determined and to solve and verify some ambiguities in the experimental IR spectra. In a series of papers, Sizova and collaborators studied different aspects of the electronic structure of $\mathrm{Ru}-\mathrm{NO}$ complexes. In a valence bond (VB) analysis, the authors concluded that the complexes in question could be represented by $\left[\mathrm{Ru}^{\mathrm{III}} \mathrm{NO}\right]{ }^{36}$ The electronic structure of some complexes containing the $\mathrm{Ru}-$ NO group was investigated by energy decomposition analysis (EDA) and by the analysis of Wiberg and Mayer bond orders. The linear Ru-NO bond was found to be predominantly covalent and $\mathrm{Ru}-\mathrm{N}$ had a high $\pi$ character, as suggested by the EDA. ${ }^{37}$ The analysis of bond orders indicated a significant degree of $\pi$ electron delocalisation over the $\mathrm{Ru}-\mathrm{NO}$ group. ${ }^{38}$ Caramori and Frenking studied some $\mathrm{Ru}^{\mathrm{II}}-\mathrm{NO}$ complexes by EDA and concluded that the orbital term and the Pauli repulsion were responsible for the weakening or strengthening of $\mathrm{Ru}-\mathrm{NO}$ bond. ${ }^{39}$ Rose and Mascharak performed DFT and TD-DFT calculations to explain the photosensitisation of the ruthenium nitrosyl group by chromophores. The calculations provided insights into the mechanism of the energy transfer from the dye fragments to the $\mathrm{Ru}-\mathrm{NO}$ group. ${ }^{40}$ Recently, a theoretical and experimental study was performed on $[\mathrm{Ru}(\mathrm{trpy})(\mathrm{tmp})(\mathrm{NO})]^{\mathrm{n}+}\left(\operatorname{trpy}=2,2^{\prime}: 6^{\prime}, 2^{\prime \prime}-\right.$ terpyridine, $\mathrm{tmp}=3,4,7,8$-tetramethyl-1,10-phenanthroline) in the $\{\mathrm{RuNO}\}^{6}$ and $\{\mathrm{RuNO}\}^{7}$ forms, which included electronic spectra. ${ }^{41}$ Among the canonical structures formerly proposed by Enemark and Feltham for $\{\text { RuNO }\}^{\mathrm{n}}$ cores,${ }^{42}$ the calculations indicated that the main resonance structures of these complexes were $\left[\mathrm{Ru}^{\mathrm{II}} \mathrm{NO}^{+}\right]$and $\left[\mathrm{Ru}^{\mathrm{III}} \mathrm{NO}\right]$, respectively, with some contribution
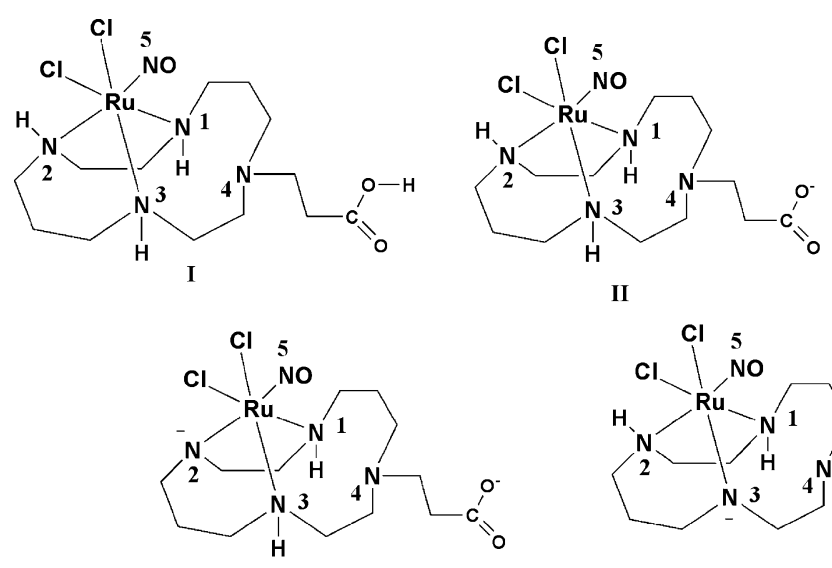

v

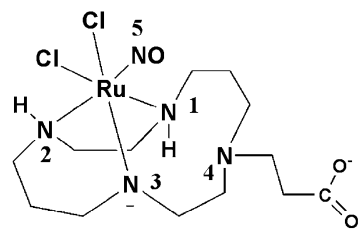

VI

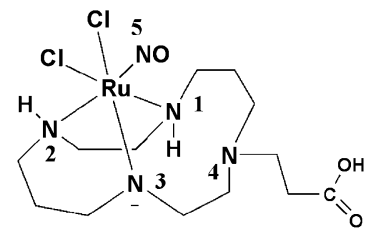

III

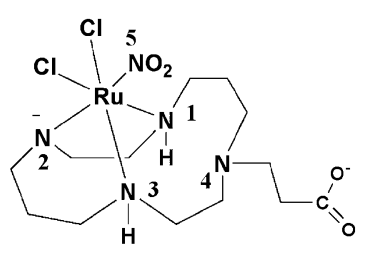

VII

Fig. 1 Structures of $f a c-\left[\mathrm{Ru}(\mathrm{NO}) \mathrm{Cl}_{2}\left(\kappa^{3} \mathrm{~N}^{4}, \mathrm{~N}^{8}, \mathrm{~N}^{11}(1-\text { carboxypropyl)cyclam })\right]^{+}(\mathrm{I})\right.$ and of the other six species studied. 
of $\left[\mathrm{Ru}^{\mathrm{I}} \mathrm{NO}^{+}\right]$for $\{\mathrm{RuNO}\}^{7}$. A sizable $\left(\mathrm{d}_{\pi}\right) \mathrm{Ru}(\mathrm{II}) \rightarrow \pi^{*}\left(\mathrm{NO}^{+}\right)$ back donation was observed for the $\{\mathrm{RuNO}\}^{6}$ complex. ${ }^{41}$ Several other studies also explored the UV-Vis spectra by computational methods. Gorelsky and Lever concluded by TD-DFT calculations that the spectra of some RuNO complexes were dominated by metal to ligand charge transfer bands. ${ }^{43}$ Lever et al. studied the electronic structure and the electronic spectra of some $\mathrm{Ru}-$ NO complexes and obtained several correlations for the ground state and spectroscopic parameters. ${ }^{44}$ The photochemistry of some $\{\mathrm{RuNO}\}^{6}$ complexes was studied and the theoretical calculations helped to explain the unusual photochemical behaviour of trans$\left[(\mathrm{NC}) \mathrm{Ru}(\mathrm{py})_{4}(\mu-\mathrm{CN}) \mathrm{Ru}(\mathrm{py})_{4}(\mathrm{NO})\right]^{3}{ }^{45}$

Herein, the chemical reactivity, photolability, and computational studies of the $f a c-\left[\mathrm{Ru}(\mathrm{NO}) \mathrm{Cl}_{2}\left(\mathrm{\kappa}^{3} \mathrm{~N}^{4}, \mathrm{~N}^{8}, \mathrm{~N}^{11}(1-\right.\right.$ carboxypropyl)cyclam)]Cl$\cdot \mathrm{H}_{2} \mathrm{O}$ (I) are reported. The unusual fac configuration influenced its chemical properties compared to analogous complexes with a trans configuration. In addition to these substantial differences, complex I could also act as a potential NO donor after electrochemical reduction or by irradiation with light. Computational studies were performed to investigate the electronic structure of $\mathbf{I}$ and to complement experimental data for the acid-base equilibria. Calculations included six deprotonated species (Fig. 1). The theoretical results indicated the preferred site for the second deprotonated species and the changes in the molecular and electronic structure that occur with deprotonation.

\section{Results and discussion}

\section{Chemical reactivity}

The $\mathrm{p} K_{\mathrm{a}}$ of the carboxyl group of (1-carboxypropyl)cyclam tetrahydrochloride was determined by potentiometric titration as being equal to $3.4 \pm 0.1$, which is close to the reported value of 3.6. ${ }^{46}$ Under similar conditions, titrations of $\mathbf{I}$ were performed (Fig. SI $1 \dagger)$, which allowed one to calculate two $\mathrm{p} K_{\mathrm{a}}$ values, $\mathrm{p} K_{\mathrm{a} 1}=3.3 \pm$ 0.1 and $\mathrm{p} K_{\mathrm{a} 2}=8.5 \pm 0.1$. For each inflection point, one acidic hydrogen was titrated according to consumed equivalents of base.

The $\mathrm{p} K_{\mathrm{a} 1}$ value of 3.3 is close to the value determined for (1carboxypropyl)cyclam tetrahydrochloride dihydrate (3.4) under the same conditions and may be attributed to the deprotonation of the carboxyl group. Because the $\mathrm{N}$ cyclam atom holding the carboxypropyl pendant group is not coordinated to the $\mathrm{Ru}$ atom in I, possible inductive effects from the metal centre to the carboxyl group are minimised, thus resulting in similar $\mathrm{p} K_{\mathrm{a}}$ values, as observed. In addition, the first deprotonation being that of the carboxyl group is consistent with theoretical calculations (see ahead). The $\mathrm{p} K_{\mathrm{a} 2}=8.5$ is probably due to the deprotonation of one $\mathrm{N}-\mathrm{H}$ group of the cyclam ring. This value is consistently lower than those reported for the free ligand (1-carboxypropyl)cyclam ${ }^{46}$ (10.11 and 11.45). The inductive effects of the $\left\{\mathrm{RuNO}^{6}\right.$ core on the hydrogen of the amine group could have led to the increase in acidity observed. In addition, this result is close to the value obtained for the first $\mathrm{N}-\mathrm{H}$ deprotonation in the $\mathrm{Ru}(\mathrm{III})$ complex trans $\left[\mathrm{RuCl}_{2}(\text { cyclam })\right]^{+}\left(\mathrm{p} K_{\mathrm{a}} \cong 7.9\right){ }^{26}$ which is also lower than those reported for the free cyclam ligand (10.6 and 11.6). ${ }^{47}$ The similarity between the $\mathrm{p} K_{\mathrm{a} 2}$ of $\mathbf{I}$ and that of trans $-\left[\mathrm{RuCl}_{2}(\mathrm{cyclam})\right]^{+}$ suggests that, following Enermark and Feltham' $\mathrm{s}^{42}$ formalism, the canonical structure for the $\{\mathrm{RuNO}\}^{6}$ core with a higher weight for this nitrosyl complex is [ $\mathrm{Ru}^{\text {III }} \mathrm{NO}$, while the others are $\left[\mathrm{Ru}^{\mathrm{II}} \mathrm{NO}^{+}\right]$ and $\left[\mathrm{Ru}^{\mathrm{IV}} \mathrm{NO}^{-}\right]$. These findings are consistent with the fact that the $\mathrm{p} K_{\mathrm{a}}$ values of the coordinated water in ruthenium nitrosyls, such as trans- $\left[\mathrm{Ru}(\mathrm{NO})\left(\mathrm{NH}_{3}\right)_{4}\left(\mathrm{OH}_{2}\right)\right]^{3+}$ and trans-[Ru(NO)(salen)$\left.\left(\mathrm{OH}_{2}\right)\right]^{+}$, are close to those reported for $\mathrm{Ru}(\mathrm{III})$ analogues. ${ }^{48,49}$

The reactivity of $\mathbf{I}$ towards $\mathrm{OH}^{-}$in aqueous solution was investigated at various $\mathrm{pH}$ values by means of differential pulse voltammetry (Fig. 2).

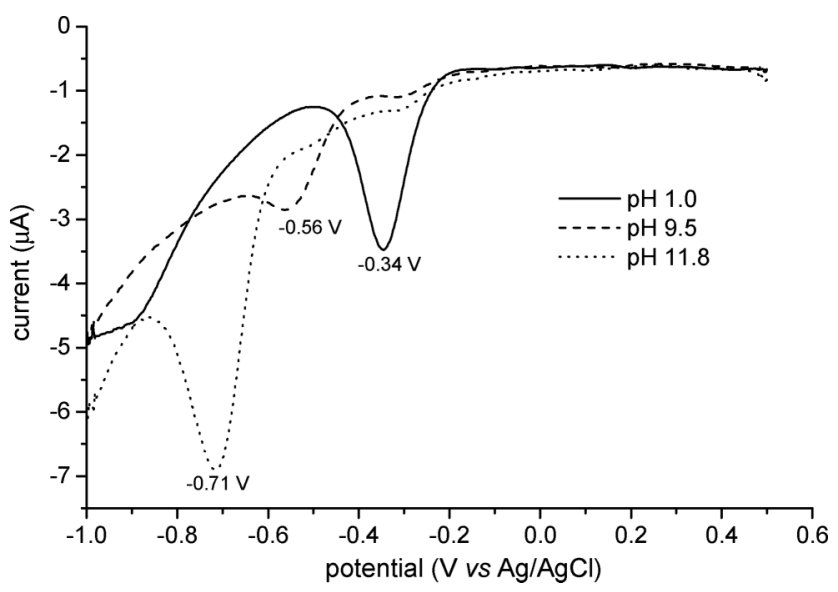

Fig. 2 Differential pulse voltammetry of $\mathbf{I}$ at different $\mathrm{pH}$ values. Initial complex concentration: $1 \times 10^{-3} \mathrm{~mol} \mathrm{~L}^{-1}$ (initial $\mathrm{pH} \sim 1, \mu=0.5 \mathrm{~mol} \mathrm{~L}^{-1}$ $\mathrm{KCl})$.

As can be seen in Fig. 2, the cathodic wave shifts to more negative potentials with increasing $\mathrm{pH}$. It was possible to estimate the $\mathrm{pK}_{\mathrm{a}}$ values from Fig. 2 to be $\sim 8.0\left(\mathrm{p} K_{\mathrm{a} 2}\right)$ and $\sim 11.5\left(\mathrm{p} K_{\mathrm{a} 3}\right)$. The $\mathrm{p} K_{\mathrm{a} 2}$ value is close to the value determined by potentiometric titrations (8.5) and even closer to that observed for the first $\mathrm{N}-\mathrm{H}$ deprotonation in trans-[ $\left.\mathrm{RuCl}_{2}(\mathrm{cyclam})\right]^{+}\left(\mathrm{p} K_{\mathrm{a}} \cong 7.9\right){ }^{26} \mathrm{The}$ shift of the cathodic peak to more negative potentials, which was detected with rising $\mathrm{pH}$, indicates that $\mathrm{p} K_{\mathrm{a} 3}(\cong 11.5)$ might have resulted from the nucleophilic attack of $\mathrm{OH}^{-}$on I. Earlier observations ${ }^{2,50,51}$ demonstrated that ruthenium nitrosyl tetraammine complexes can undergo nucleophilic attack by $\mathrm{OH}^{-}$, which could result in the respective nitro $\left(\mathrm{Ru}^{\mathrm{II}}-\mathrm{NO}_{2}^{-}\right)$complex. This behaviour was attributed to the nitrosonium character of the NO ligand in such complexes. ${ }^{2,51}$ The NO infrared stretching frequency, $v_{(\mathrm{NO})}$, of $\mathbf{I}\left(1881 \mathrm{~cm}^{-1}\right)$ was consistent with the $\left[\mathrm{Ru}^{\mathrm{II}} \mathrm{NO}^{+}\right]$canonical form, but the linearity of the $\mathrm{Ru}-\mathrm{N}-\mathrm{O}$ bond angle was slightly off $\left(167.7(2)^{\circ}\right),{ }^{7}$ which suggested some contribution from the $\left[\mathrm{Ru}^{\mathrm{III}} \mathrm{NO}\right]$ canonical form.

That equilibrium (see Scheme 1 below) can occur as a two-step process beginning with the $\mathrm{OH}^{-}$addition to the nitrosyl complex followed by an additional attack by a second $\mathrm{OH}^{-} .{ }^{51}$ The presence of three species as products of the equilibrium reactions with $\mathrm{OH}^{-}$is supported by the observed reversibility. After the solution reached $\mathrm{pH} \sim 12$, the $\mathrm{pH}$ was carefully and slowly decreased by addition of $\mathrm{HCl}$ solution. The cathodic waves reappeared at the same potentials. In addition, when I was dissolved in solutions with $\mathrm{pH}$ previously adjusted to $1.0,9.5$, and 12.0 , only one cathodic wave was observed in each case and at the same potentials reported above. Accordingly, the following equilibria can be proposed (Scheme 1). 


$$
\begin{aligned}
& \text { I } \underset{+\mathrm{H}^{+}}{\stackrel{-\mathrm{H}^{+}}{\rightleftarrows}} \text { II } \quad \mathrm{pKa}_{1}=3.3 \\
& \text { II } \underset{+\mathrm{H}^{+}}{\stackrel{-\mathrm{H}^{+}}{\rightleftarrows}} \mathrm{V} \quad \mathrm{pKa}_{2} \sim 8.0 \\
& \mathrm{~V} \underset{+\mathrm{H}^{+}}{\stackrel{+2 \mathrm{OH}^{-}}{\rightleftarrows}} \mathrm{VII}+\mathrm{H}_{2} \mathrm{O} \quad \mathrm{pKa}_{3} \sim 11.5
\end{aligned}
$$

Scheme 1 Proposed acid-base equilibria for $\mathbf{I}$.

The lability of the chloro ligands coordinated to the $\mathrm{Ru}$ atom in I was investigated by direct potentiometry using a chloride selective electrode. When a freshly prepared $2.5 \times 10^{-4} \mathrm{~mol} \mathrm{~L}^{-1}$ solution of $\mathbf{I}\left(\mu=0.1 \mathrm{~mol} \mathrm{~L}^{-1} \mathrm{KNO}_{3}, \mathrm{pH} 3\right)$ at $25 \pm 1{ }^{\circ} \mathrm{C}$ was analysed, the chloride concentration was determined to be $2.2 \pm$ $0.2 \times 10^{-4} \mathrm{~mol} \mathrm{~L}^{-1}$, which was consistent with the presence of one counter-ion, as expected. The measured current remained essentially the same even after $2 \mathrm{~h}$. Furthermore, aqueous solutions of $\mathbf{I}$ analysed by UV-Vis spectroscopy for $9 \mathrm{~h}$ did not present any spectral change that would indicate chloride aquation. Inertness of the ligand in an aqueous solution at room temperature was confirmed by electrospray ionisation mass spectrometry (ESIMS). When a three-day-old solution of I was analysed by ESIMS, the spectrum showed a cluster of isotopologues in the same $m / z$ range of 468.2 to 480.2 as was observed earlier for freshly prepared solutions, ${ }^{7}$ which characterised a species containing a single $\mathrm{Ru}$ and two $\mathrm{Cl}$ atoms. The isotopic pattern was therefore consistent with a $\mathrm{C}_{13} \mathrm{H}_{28} \mathrm{O}_{3} \mathrm{~N}_{5} \mathrm{RuCl}_{2}$ composition ${ }^{7}$ and provided further support to the inertness of the chloro ligands with regards to the substitution.

The substitution inertness of chloro ligands in ruthenium ammine complexes is dependent on their configuration (cis or trans) and the metal oxidation state (Ru(II) or $\mathrm{Ru}(\mathrm{III})) .{ }^{1}$ Generally, aquation rates increase from $\mathrm{Ru}(\mathrm{III})$ to $\mathrm{Ru}(\mathrm{II})$ and from trans to cis complexes. ${ }^{1}$ For instance, in tetraammine Ru complexes, such as $\left[\mathrm{RuCl}\left(\mathrm{NH}_{3}\right)_{5}\right] \mathrm{Cl}_{2}\left(k_{-\mathrm{Cl}}=3.1 \times 10^{-6} \mathrm{~s}^{-1} \text { at } 25^{\circ} \mathrm{C}\right)^{52}$ and trans$\left[\mathrm{RuCl}_{2}\left(\mathrm{NH}_{3}\right)_{4}\right] \mathrm{Cl}\left(k_{-\mathrm{Cl}}=1.7 \times 10^{-6} \mathrm{~s}^{-1}\right.$ at $\left.25^{\circ} \mathrm{C}\right)$, the chloro ligands have been found to be inert towards aquation reactions, while in complexes such as trans- $\left[\mathrm{RuCl}_{2}\left(\mathrm{NH}_{3}\right)_{4}\right]\left(k_{\mathrm{obs}}=0.9 \mathrm{~s}^{-1}\right.$ at $\left.25^{\circ} \mathrm{C}\right)$ and cis- $\left[\mathrm{RuCl}_{2}\left(\mathrm{NH}_{3}\right)_{4}\right]\left(k_{\text {obs }} \sim 32 \mathrm{~s}^{-1}\right.$ at $\left.25^{\circ} \mathrm{C}\right),{ }^{53}$ the chloro ligands are labile. However, it has been reported that in ruthenium complexes with aliphatic tetraazamacrocylic ligands, the same lability is not observed. For example, in trans- $\left[\mathrm{RuCl}_{2} \text { (cyclam) }\right]^{+}$no aquation reaction was observed within $24 \mathrm{~h}$. For cis-[ $\mathrm{RuCl}_{2}$ (cyclen) $]^{+}$ (cyclen $=1,4,7,10$-tetraazacyclododecane), the observed aquation reaction rate, $k_{\text {obs }}$, was $3.6 \times 10^{-3} \mathrm{~s}^{-1}$ at $25^{\circ} \mathrm{C}$. $\mathrm{Ru}(\mathrm{II})$ centers, ${ }^{1,25}$ however, have increased chloro lability, as in trans-[ $\mathrm{RuCl}_{2}$ (cyclam)] $\left(k_{\text {obs }}=0.036 \mathrm{~s}^{-1}\right.$ at $\left.25^{\circ} \mathrm{C}\right),{ }^{1}$ but they are still considered inert compared to analogous ammine complexes. The inertness of the chloro ligands towards substitution in ruthenium cyclam complexes such as trans-[RuCl(cyclam $)(4-\mathrm{acpy})]\left(\mathrm{BF}_{4}\right){ }^{5}$ trans$[\mathrm{Ru}(\mathrm{NO}) \mathrm{Cl}($ cyclam $)]\left(\mathrm{ClO}_{4}\right)_{2},{ }^{6}$ and trans- $\left[\mathrm{RuCl}_{2}(\right.$ cyclam $\left.)\right] \mathrm{Br}^{14}$ was attributed to interactions between $\mathrm{Cl}$ and $\mathrm{H}-\mathrm{N}$. These complexes have $\mathrm{Cl} \cdots \mathrm{H}-\mathrm{N}$ interatomic distances of $2.70 \AA$, $2.43 \AA$ and $2.71 \AA$, respectively, which are smaller than the sum of the van der Waals radii for $\mathrm{H}$ and $\mathrm{Cl}(3.0-3.3 \AA)$. The intramolecular distances $\mathrm{Cl} \cdots \mathrm{H}-\mathrm{N}$ of $2.652 \AA$ and $3.150 \AA$ in $\mathbf{I}^{7}$ suggested that similar inertness was expected. Although the distance of $3.150 \AA$ is large, it is still within the range of the van der Waals radii. The absence of chloro labilization at room temperature in I suggests that $\mathrm{Cl} \cdots \mathrm{H}-$ $\mathrm{N}$ intramolecular interatomic distances are short enough to make the chloro ligands inert towards aquation reactions. However, an increase in the temperature to $40 \pm 1{ }^{\circ} \mathrm{C}$ under the same conditions resulted in one chloro ligand aquation with $k_{\mathrm{obs}}=$ $5.6 \pm 0.3 \times 10^{-5} \mathrm{~s}^{-1}$ and $t_{1 / 2}=1.2 \times 10^{4} \mathrm{~s}^{-1}$. It seems reasonable to assume that the aquation reaction more likely proceeds on the $\mathrm{Cl}^{-}$ligand that has the $\mathrm{Cl} \cdots \mathrm{H}-\mathrm{N}$ interatomic distance of $3.150 \AA$. Although the aquation rate constant was obtained at $40{ }^{\circ} \mathrm{C}$, these results indicated that the inertness of the chloro ligand in $\mathbf{I}$ is similar to that observed for $\mathrm{Ru}(\mathrm{III})$ complexes such as trans$\left[\mathrm{RuCl}_{2}\left(\mathrm{NH}_{3}\right)_{4}\right] \mathrm{Cl}\left(k_{\text {obs }}=1.7 \times 10^{-6} \mathrm{~s}^{-1}\right.$ at $\left.25^{\circ} \mathrm{C}\right)$ and trans $-\left[\mathrm{RuCl}_{2}(1-\right.$ (3-propylammonium)cyclam) $]^{+}\left(k_{\text {obs }}=8.2 \times 10^{-5} \mathrm{~s}^{-1} \text { at } 25^{\circ} \mathrm{C}\right)^{10}$ that also contains a mono-N-substituted cyclam ligand. In the latter complex, the chloro aquation rate is larger than that for trans$\left[\mathrm{RuCl}_{2}(\right.$ cyclam $\left.)\right] \mathrm{Cl}$, which is consistent with the weakening of one hydrogen-bonding interaction due to $\mathrm{N}$-substitution.

The chloro aquation was also investigated after one electron reduction by bulk controlled potential electrolysis and chemical reduction with an $\mathrm{Eu}^{2+}$ solution. A fast aquation of two chloride ligands was observed in both cases. Because of the experimental conditions used in the reduction, it was not possible to obtain aquation rate constants for these reactions.

\section{Electrochemistry}

Redox potentials ( $v s . \mathrm{Ag} / \mathrm{AgCl}$ ) for I and some selected ruthenium nitrosyl tetraazamacrocyclic complexes are displayed in Table 1.

The cyclic voltammogram of $\mathbf{I}$ in the same medium where the crystals were grown $\left(0.5 \mathrm{~mol} \mathrm{~L}^{-1} \mathrm{HCl}\right)$ displayed one cathodic peak at $-0.39 \mathrm{~V}(1 \mathrm{c})$ and one anodic peak near $-0.16 \mathrm{~V}(2 \mathrm{a})$ in the range of +0.8 to $-0.8 \mathrm{~V}$ (vs. $\mathrm{Ag} / \mathrm{AgCl}$ ) (Fig. 3). In this medium, this behaviour remained unchanged with scan rates from 0.01 up to $1 \mathrm{~V} \mathrm{~s}^{-1}$ and in the temperature range of 4 to $25^{\circ} \mathrm{C}$. The $E_{\mathrm{pc}}$ for $\mathbf{I}$ is close to those observed for the analogous complexes, which was attributed to the $\{\mathrm{RuNO}\}^{6 / 7}$ core reduction (Table 1). The $\{\mathrm{RuNO}\}^{6 / 7}$ process for trans-[Ru(NO)Cl(cyclam) $]^{2+}$ and trans-[Ru(NO)Cl(1(3-propylammonium)cyclam) $]^{3+}$ was reversible in the presence of

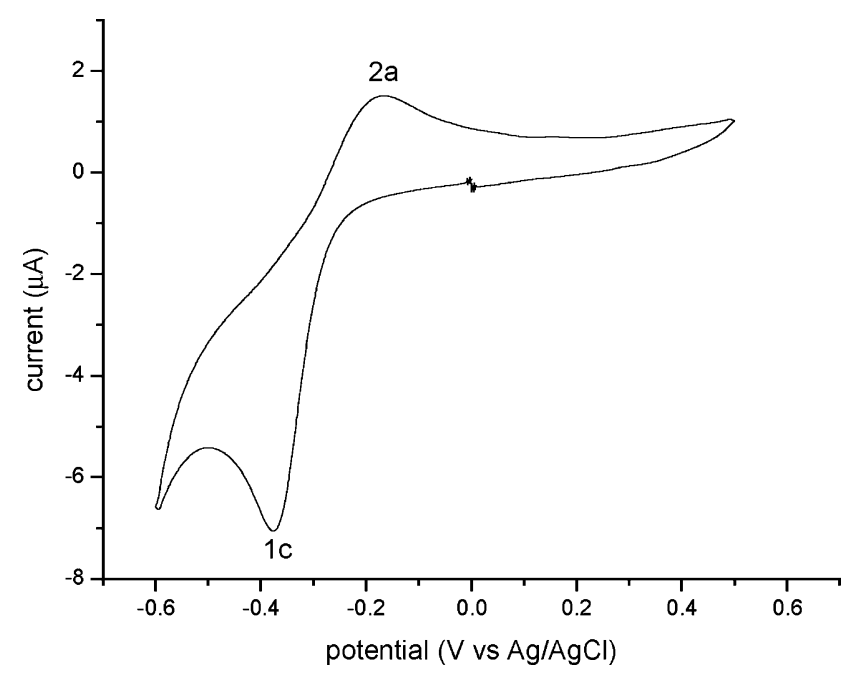

Fig. 3 Cyclic voltammogram of $\mathbf{I}$ in $0.5 \mathrm{~mol} \mathrm{~L}^{-1} \mathrm{HCl}$ at $25^{\circ} \mathrm{C}$ and scan rate of $25 \mathrm{mV} \mathrm{s}^{-1}$. 
Table $1\left\{\mathrm{RuNO}^{6 / 7}\right.$ reduction potentials of some ruthenium nitrosyl complexes with cyclam and related ligands

\begin{tabular}{|c|c|c|}
\hline Complex & $E_{\mathrm{pc}}(\mathrm{V})^{a}$ & Ref. \\
\hline trans $-[\mathrm{Ru}(\mathrm{NO}) \mathrm{Cl}(\text { cyclam })]^{2+b}$ & -0.37 & 6 \\
\hline trans $-[\mathrm{Ru}(\mathrm{NO}) \mathrm{Cl}(1-(3 \text {-propylammonium }) \text { cyclam })]^{3+c}$ & -0.34 & 10 \\
\hline trans-[Ru(NO) $\left.\mathrm{Cl}\left(15 \mathrm{aneN}_{4}\right)\right]^{2+d}$ & -0.28 & 28 \\
\hline fac- $\left[\mathrm{Ru}(\mathrm{NO}) \mathrm{Cl}_{2}\left(\kappa^{3} \mathrm{~N}^{4}, \mathrm{~N}^{8}, \mathrm{~N}^{11} \text { (1-carboxypropyl)cyclam) }\right]^{+e}\right.$ & -0.39 & this work \\
\hline
\end{tabular}

excess chloride, so the cyclic voltammogram (CV) displays both the corresponding cathodic and anodic peaks. ${ }^{6,8}$ The one electron reduction of these two latter complexes was followed by fast chloro aquation in the absence of chloride ions in solution. ${ }^{1,6,8}$ The absence of the corresponding anodic peak (1a) for the reduction wave (1c) in the cyclic voltammograms of $\mathbf{I}$ (Fig. 3) suggests that NO labilisation is faster compared to the analogous complexes with cyclam and 1-(3-propylammonium)cyclam ligands. The NO release from $\mathbf{I}$ is supported by in situ electrochemical NO detection when its $0.5 \mathrm{~mol} \mathrm{~L}^{-1} \mathrm{HCl}$ solution was submitted to controlled potential electrolysis at $-0.5 \mathrm{~V}$.

The monoelectronic reduction assigned to the $\{\mathrm{RuNO}\}^{6}$ core in ruthenium ammine nitrosyl complexes results in NO dissociation whose specific rate constants $\left(k_{\text {-NO }}\right)$ depend on the equatorial and axial ligands. For instance, in trans $-\left[\mathrm{Ru}(\mathrm{NO})\left(\mathrm{NH}_{3}\right)_{4}(\mathrm{~L})\right]^{\mathrm{n}+}(\mathrm{L}=$ nitrogen heterocyclic bases) the $k_{\text {-NO }}$ values depend on the Lligand in the trans position to $\mathrm{NO}$ and span a range of $5.1 \mathrm{~s}^{-1}$ ( $\mathrm{L}=C$-bound imidazole) to $0.02 \mathrm{~s}^{-1}\left(\mathrm{~L}=4\right.$-picoline). ${ }^{2}$ However, for trans-[Ru(NO) $\left(\mathrm{OH}_{2}\right)($ cyclam $\left.)\right]^{3+}$ it was found to be much lower $\left(k_{\text {-NO }}=6.1 \times 10^{-4} \mathrm{~s}^{-1}\right)$. ${ }^{2,6}$ The rate of NO dissociation in I was investigated by cyclic voltammetry using platinum microelectrode and was estimated to be $k_{\text {obs-No }}=2.8 \mathrm{~s}^{-1}$ at $25 \pm 1{ }^{\circ} \mathrm{C}$ (in $0.5 \mathrm{~mol} \mathrm{~L}^{-1}$ $\mathrm{HCl}$ aqueous solution), which is close to the highest specific rate constant of NO release observed for trans-[Ru(NO) $\left.\left(\mathrm{NH}_{3}\right)_{4}(\mathrm{~L})\right]^{\mathrm{n}+}$, and approximately four orders of magnitude larger than that observed for trans-[Ru(NO) $\left(\mathrm{H}_{2} \mathrm{O}\right)($ cyclam $\left.)\right]^{3+}$. However, due to the high complexity of the electrode reactions (see below), it is difficult to provide an appropriate parallel with $k_{\text {-NO }}$ values such as those determined for trans-[Ru(NO)( $\left.\mathrm{H}_{2} \mathrm{O}\right)($ cyclam $\left.)\right]^{3+}$ and trans$\left[\mathrm{Ru}(\mathrm{NO})\left(\mathrm{NH}_{3}\right)_{4}(\mathrm{~L})\right]^{\mathrm{n}+}$ complexes.

The electrode reactivity for $\mathbf{I}$ in aqueous solution is more complicated than that observed for analogous complexes, like trans- $[\mathrm{Ru}(\mathrm{NO}) \mathrm{Cl}(\text { cyclam })]^{2+}$, because it is possible to assume that both chloro ligands and NO can undergo aquation reactions after $\{\mathrm{RuNO}\}^{6}$ reduction and probably at different rates. The anodic peak (2a) observed in the cyclic voltammograms of $\mathbf{I}$ is highly dependent on conditions of analysis such as $\mathrm{pH}$, chloride concentration, scan rate, and temperature, while the cathodic peak essentially remains at the same potential (Fig. 4). At pH values of 1.0 (below $\mathrm{p} K_{\mathrm{a} 1}$ (carboxypropyl group)) and 4.7 the $\mathrm{CV}$ profile is essentially the same as the one observed in $0.5 \mathrm{~mol} \mathrm{~L}^{-1} \mathrm{HCl}$ (Fig. 3), but with the anodic peak (2a), which appears at $-0.16 \mathrm{~V}$ at $0.5 \mathrm{~mol} \mathrm{~L}^{-1} \mathrm{HCl}$, broadened and shifted to around $-0.24 \mathrm{~V}$. The cathodic (1c) and anodic (2a) peaks do not seem to correspond to the same redox process, because $\Delta E>\sim 110 \mathrm{mV}$ and $I_{\mathrm{pa}} / I_{\mathrm{pc}}$ $\sim 0.5$. Peak $2 \mathrm{a}$ is better resolved with scan rates of $20 \mathrm{mV} \mathrm{s}^{-1}$ at $\mathrm{pH} 4.7$ and $\left[\mathrm{Cl}^{-}\right]$of 0 and $0.1 \mathrm{~mol} \mathrm{\textrm {L } ^ { - 1 }}$ at $25^{\circ} \mathrm{C}$ and in the absence of chloride at $4^{\circ} \mathrm{C}$. At $\mathrm{pH} 4.7$, where the carboxypropyl group is deprotonated and, thus, able to bind to $\mathrm{Ru}$, the influence of

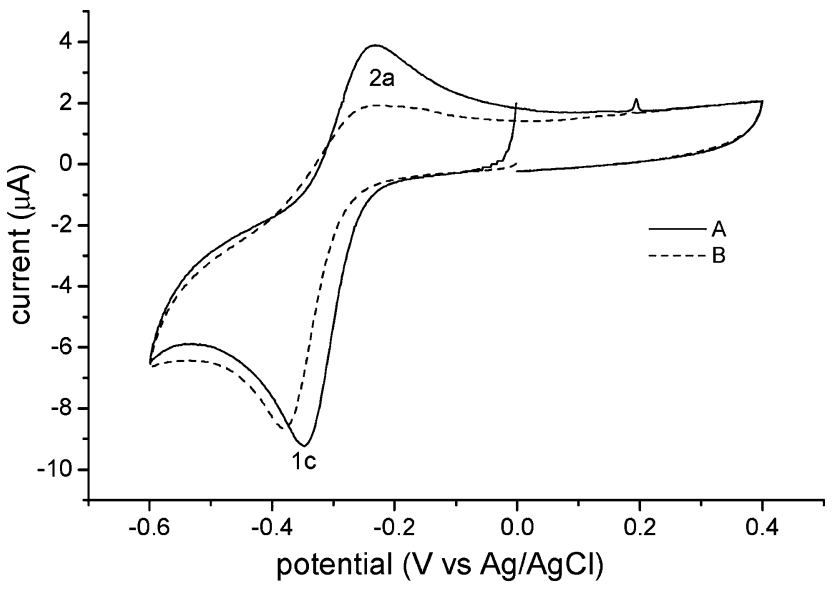

Fig. 4 Cyclic voltammograms in aqueous solution for $\mathbf{I}$ at $25^{\circ} \mathrm{C}$ and scan rate of $20 \mathrm{mV} \mathrm{s}^{-1}$ unless otherwise stated. Curve (A) was obtained

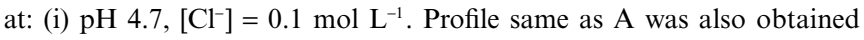

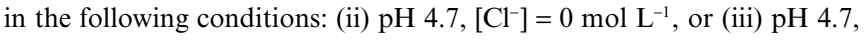
$\left[\mathrm{Cl}^{-}\right]=0 \mathrm{~mol} \mathrm{~L}^{-1}$, at $4{ }^{\circ} \mathrm{C}$. Curve (B) was obtained at (iv) $\mathrm{pH} 1,\left[\mathrm{Cl}^{-}\right]=$ $0.1 \mathrm{~mol} \mathrm{~L}^{-1}$. Profile same as $\mathrm{B}$ was obtained in the following conditions: (v) $\mathrm{pH} 1,\left[\mathrm{Cl}^{-}\right]=0$ or $4.0 \mathrm{~mol} \mathrm{~L}^{-1}$, (vi) $\mathrm{pH} 4.7,\left[\mathrm{Cl}^{-}\right]=4.0 \mathrm{~mol} \mathrm{~L}^{-1}$, (vii) pH $4.7,\left[\mathrm{Cl}^{-}\right]=0.1 \mathrm{~mol} \mathrm{~L}^{-1}$, scan rates $>100 \mathrm{mV} \mathrm{s}^{-1}$; (viii) $\mathrm{pH} 4.7,\left[\mathrm{Cl}^{-}\right]=$ $0.1 \mathrm{~mol} \mathrm{~L}^{-1}$, at $4{ }^{\circ} \mathrm{C}$.

$\left[\mathrm{Cl}^{-}\right]$, scan rate, and temperature was also investigated. Comparing the conditions (i) and (ii) to (vi) it is possible to infer that $\left[\mathrm{Cl}^{-}\right]$ influences only in large excess. Peak $2 \mathrm{a}$ is better resolved at lower scan rates (comparison of conditions (i) and (vii)) and at $25^{\circ} \mathrm{C}$, a borderline situation appears at $4{ }^{\circ} \mathrm{C}$ where the better resolved peak in the absence of chloride is broadened with a $\left[\mathrm{Cl}^{-}\right]$of just $0.1 \mathrm{~mol} \mathrm{~L}^{-1}$. Among the several possible reactions after reduction, one is the coordination of the carboxylate group after labilisation of at least one of the ligands $(\mathrm{Cl}$ or $\mathrm{NO})$. In the presence of a large excess of chloride ions, in which the anodic peak (2a) is also broadened and poorly resolved (condition (vi), Fig. 4), the equilibrium of the aquation reaction after NO release should be shifted towards the chloro complex; thus, the proposed carboxyl coordination would be unfavorable. Therefore, the $\mathrm{CV}$ would be similar to those obtained at $\mathrm{pH} 1$, as observed. Because the proposed coordination of carboxyl group must be preceded by the labilisation of chloro (or NO) ligand, one would expect that the scan rate and temperature would affect this step. If the cyclic voltammograms are recorded with scan rates of $100 \mathrm{mV} \mathrm{s}^{-1}$ or more (or the temperature is lowered to $4{ }^{\circ} \mathrm{C}$ ) (conditions (vii) and (viii), respectively, Fig. 4) the anodic wave (2a), which was well resolved at scan rate of $20 \mathrm{mV} \mathrm{s}^{-1}$ and $T=25^{\circ} \mathrm{C}$, should become poorly resolved (Fig SI 2 and $3 \dagger$ ), as observed. Thus, these findings support the hypothesis of a coupled reaction in 
the reduction process, possibly the ligand labilisation followed by carboxylate coordination. This type of coordination has been reported for $\mathrm{Ni}$ and $\mathrm{Cu}$ complexes with cyclam ligands bearing amino or carboxyl pendant arms, and it depends on $\mathrm{pH}$, resulting in differences in spectroscopic and electrochemical properties. ${ }^{54-56}$ Although the idea of the coordination of the carboxyl substituent seems reasonable, it is still necessary to identify which ligand is being replaced, $\mathrm{Cl}^{-}$or NO. A possibility can be drawn from the comparison of cyclic voltammograms at $4{ }^{\circ} \mathrm{C}$ in $0.1 \mathrm{~mol} \mathrm{~L}^{-1}$ $\mathrm{NaNO}_{3}$ and $\mathrm{NaCl}\left(\mathrm{pH} 4.7\right.$, scan rate $20 \mathrm{mV} \mathrm{s}^{-1}$ ) (Fig SI $4 \dagger$ ). At this temperature, the concentration of $0.1 \mathrm{~mol} \mathrm{~L}^{-1}$ chloride ions seems to be sufficient to shift the equilibrium towards the chloro complex, thereby inhibiting the proposed coordination of the carboxyl group. Thus, it was more likely that at least one of the chloro ligands was labilised faster than the nitrosyl ligand after the electrochemical reduction and the vacant position being possibly occupied by the carboxyl group.

\section{Photolability}

Ruthenium nitrosyl complexes with macrocyclic ligands (trans$\left.[\mathrm{Ru}(\mathrm{NO}) \mathrm{Cl}(\mathrm{mac})]^{2+}\right)(\mathrm{mac}=$ tetraazamacrocyle $)$, such as cyclam and 1,4,8,12-tetraazacyclopentadecane (15aneN4), have been shown to release NO when irradiated with light of 314, 334, and $355 \mathrm{~nm}^{1,2,8,11,28,57}$ like other ruthenium nitrosyl ammine complexes, such as trans- $\left[\mathrm{Ru}(\mathrm{NO})\left(\mathrm{NH}_{3}\right)_{4}(\mathrm{~L})\right]^{3+}(\mathrm{L}=$ nitrogen heterocyclic bases). ${ }^{2,29,49,57}$ Irradiation of the former complexes led to the corresponding aquo (or hydroxo, depending on the $\mathrm{pH}$ ) $\mathrm{Ru}(\mathrm{III})$ complex and NO (Eqn. 1), without chloride aquation. ${ }^{1}$

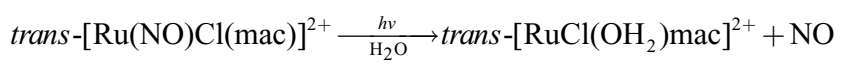

Investigations on the photolabilisation of NO from I in phosphate buffer solution ( $\mathrm{pH}$ 7.4) were performed under irradiation with light at 350 and $520 \mathrm{~nm}$ in the presence of the NO scavenger myoglobin ${ }^{58} \mathrm{Mb}(\mathrm{III})$ (Fig. 5). Direct reactions of $\mathrm{NO}$ with iron metalloproteins, such as $\mathrm{Mb}(\mathrm{III})$ and the related haemoglobin and cytochrome $\mathrm{C}$, are among the most important reactions in which $\mathrm{NO}$ participates. ${ }^{59}$ In vitro, $\mathrm{Mb}$ (III) reacts with $\mathrm{NO}$ forming $\mathrm{Mb}(\mathrm{III}) \mathrm{NO}$ that reacts with $\mathrm{OH}^{-}$leading to nitrite and $\mathrm{Mb}$ (II); then, $\mathrm{Mb}$ (II) reacts with $\mathrm{NO}$ forming $\mathrm{Mb}$ (II)NO. ${ }^{60}$ In phosphate buffer solution at $\mathrm{pH} 7.4, \mathrm{Mb}(\mathrm{III})$ displays a Soret absorption maximum at $408 \mathrm{~nm}\left(1.5 \times 10^{5} \mathrm{~mol} \mathrm{~L}^{-1} \mathrm{~cm}^{-1}\right)$ and a band at $500 \mathrm{~nm}$ $\left(1 \times 10^{4} \mathrm{~mol} \mathrm{~L}^{-1} \mathrm{~cm}^{-1}\right)$ in the Q-band region, ${ }^{60,61}$ whereas $\mathrm{Mb}$ (II)NO presents a band at $420 \mathrm{~nm}\left(1.29 \times 10^{5} \mathrm{~mol} \mathrm{~L}^{-1} \mathrm{~cm}^{-1}\right)$ and two bands at 545 and $578 \mathrm{~nm}$ in the Q-band region. For comparison

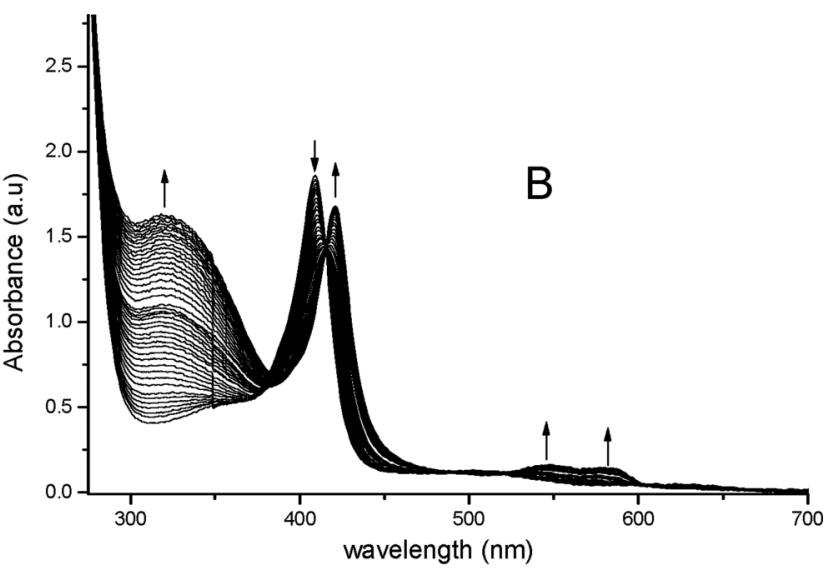

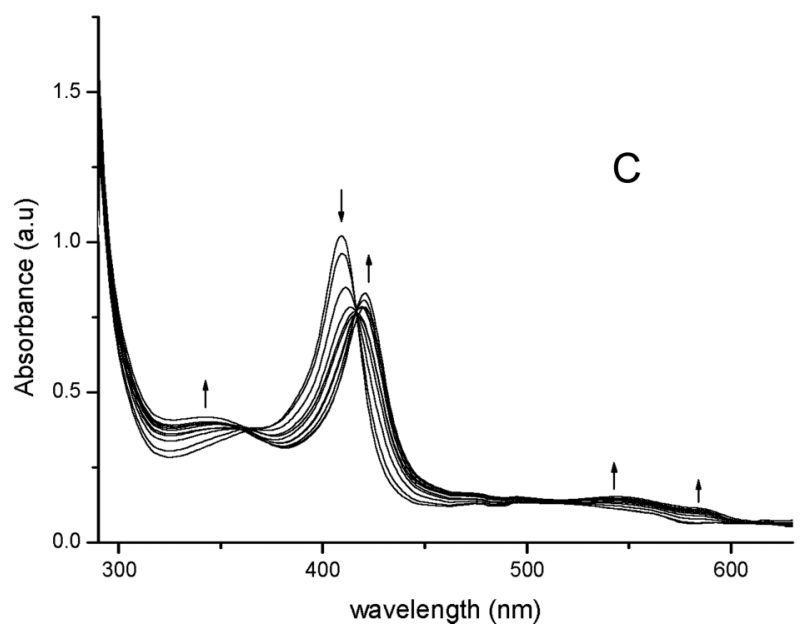

Fig. 5 Spectral changes during photolysis of $\mathbf{I}(\mathrm{A})$ and trans- $\left[\mathrm{Ru}(\mathrm{NO})\left(\mathrm{NH}_{3}\right)_{4}(\mathrm{py})\right]^{3+}(\mathrm{B})$ with light of $350 \mathrm{~nm}$ in phosphate buffer solution (pH 7.4) in the presence of $\mathrm{Mb}(\mathrm{III})$. (C) Irradiation with light of $520 \mathrm{~nm}$ of $\mathbf{I}$ in phosphate buffer solution (pH 7.4) in the presence of $\mathrm{Mb}$ (III). 


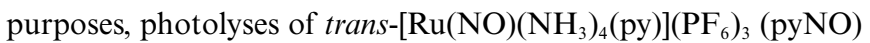
were performed using irradiation with $\lambda_{\text {irr }}=350 \mathrm{~nm}$ under the same conditions. This complex releases NO with $\phi_{\mathrm{Ru}}=0.18 \pm 0.01\left(\lambda_{\text {irr }}=\right.$ $330 \mathrm{~nm}, \mathrm{pH} 6.4)^{29}$ Irradiation with $\lambda_{\text {irr }} \geq 380 \mathrm{~nm}$ (at $25^{\circ} \mathrm{C}$ ) did not result in any observable photoreaction in solution for trans$\left[\mathrm{Ru}(\mathrm{NO})\left(\mathrm{NH}_{3}\right)_{4}(\mathrm{~L})\right]^{\mathrm{n}+}$ or trans $-[\mathrm{Ru}(\mathrm{NO}) \mathrm{Cl}(\mathrm{mac})]^{\mathrm{n}+}(\mathrm{mac}=$ cyclam, 15aneN4, or 1-(3-aminopropyl)cyclam). . $^{1,2,8,28,29}$

Fig. 5 shows that upon light irradiation the Mb(III) Soret band at $408 \mathrm{~nm}$ decreases, with the appearance of three new bands, one at $420 \mathrm{~nm}$ and two at 542 and $578 \mathrm{~nm}$ in the Q-band region. An additional band also appears at $330 \mathrm{~nm}$. As judged from photolysis experiments of $\mathbf{I}$ in the absence of $\mathrm{Mb}$ (III) under the same conditions, this band is probably due to the presence of a $\mathrm{Ru}(\mathrm{III})$ complex as photoproduct. The appearance of a band in the same region was also observed during light irradiation of trans-[Ru(NO) $\left.\left(\mathrm{NH}_{3}\right)_{4}(\mathrm{py})\right]^{3+}$, which has been attributed to the formation of trans- $\left[\mathrm{Ru}(\mathrm{OH})\left(\mathrm{NH}_{3}\right)_{4}(\mathrm{py})\right]^{2+}$ at this $\mathrm{pH} .{ }^{29}$ These spectral changes can be interpreted as the result of NO being released from I (or pyNO) with the consequential reductive nitrosylation of $\mathrm{Mb}$ (III), which led to $\mathrm{Mb}$ (II) $\mathrm{NO}$ as the final product. The spectrum of authentic $\mathrm{Mb}(\mathrm{II})(\mathrm{NO})$ formed by the direct reaction of $\mathrm{Mb}$ (II) and $\mathrm{NO}$ also displayed a high intensity absorption band at $420 \mathrm{~nm}\left(1.29 \times 10^{5} \mathrm{~mol} \mathrm{~L}^{-1} \mathrm{~cm}^{-1}\right)$ and lower intensity bands at 545 and $578 \mathrm{~nm} .{ }^{60,61}$ In addition, the photolysis of the trans- $\left[\mathrm{Ru}\left(\mathrm{NH}_{4}\right)\left(\mathrm{NO}_{2}\right)\left(\mathrm{P}\left(\mathrm{OEt}_{3}\right)\right)\right]^{3+}$ solution, which led to $\mathrm{NO}$ production by a radical mechanism, ${ }^{58}$ also resulted in a very similar spectral pattern due to the reductive nitrosylation of $\mathrm{Mb}(\mathrm{III})$. These results suggest that irradiation at $520 \mathrm{~nm}$ is able to promote NO photolabilization. Complex I showed a low intensity (log $\varepsilon=1.88)$ broad band with an absorption maximum centered at $532 \mathrm{~nm}^{7}$; a $\mathrm{Ru}_{\mathrm{d} \pi}-\pi^{*}(\mathrm{NO})$ transition could have contributed to this because irradiation of light in bands with such origin have shown to be responsible for NO photoaquation ${ }^{1,2,29}$ from other $\mathrm{Ru}$ nitrosyls. As far as we know, this is the first example of a ruthenium nitrosyl complex with a saturated cyclic amine that is able to release $\mathrm{NO}$ with irradiation of light in the visible range. To understand the origin of such a behaviour, further studies will be necessary.

\section{Computational studies}

Among the several computational models tested (see ESI, Table SI $1 \dagger$ ) for the bond lengths of the fully protonated fac- $\left[\mathrm{Ru}(\mathrm{NO}) \mathrm{Cl}_{2}\left(\kappa^{3} \mathrm{~N}^{4}, \mathrm{~N}^{8}, \mathrm{~N}^{11}(1 \text {-carboxypropyl)cyclam) }]^{+}\right.\right.$, (I), the B3LYP/ECP28MDF, cc-pVDZ model was determined to be the most adequate. The geometry of $\mathbf{I}$ was compared with species already observed, or conceivably possible, in solution at different pHs, as follows: deprotonated at the carboxyl, (II); deprotonated at $\mathrm{N} 3$, (III); deprotonated at the carboxyl group and in N1, (IV), or at $\mathrm{N} 2,(\mathbf{V})$, or at $\mathrm{N} 3(\mathbf{V I})$; and $f a c-\left[\mathrm{Ru}\left(\mathrm{NO}_{2}\right) \mathrm{Cl}_{2}\left(\mathrm{\kappa}^{3} \mathrm{~N}^{4}, \mathrm{~N}^{8}, \mathrm{~N}^{11}(1-\right.\right.$ $\mathrm{C}_{2} \mathrm{H}_{4}$-COO)cyclam) $]^{-}$deprotonated at the carboxyl and at $\mathrm{N} 2$ (VII) (see Fig. 1). The atom numbering is the same as that used in the crystallographic study of $\mathbf{I},{ }^{7}$ and is represented in Fig. 6. III was studied because II has a very short $\mathrm{O} 12-\mathrm{H}[\mathrm{N} 3]$ hydrogen bond and long N3-H, indicating the possibility of spontaneous migration of this hydrogen to O12. IV, V, and VI were studied because it was not possible to determine the most favourable site for the second deprotonation experimentally. Finally, VII was studied because $\mathbf{V}$ is the most stable di-deprotonated form.

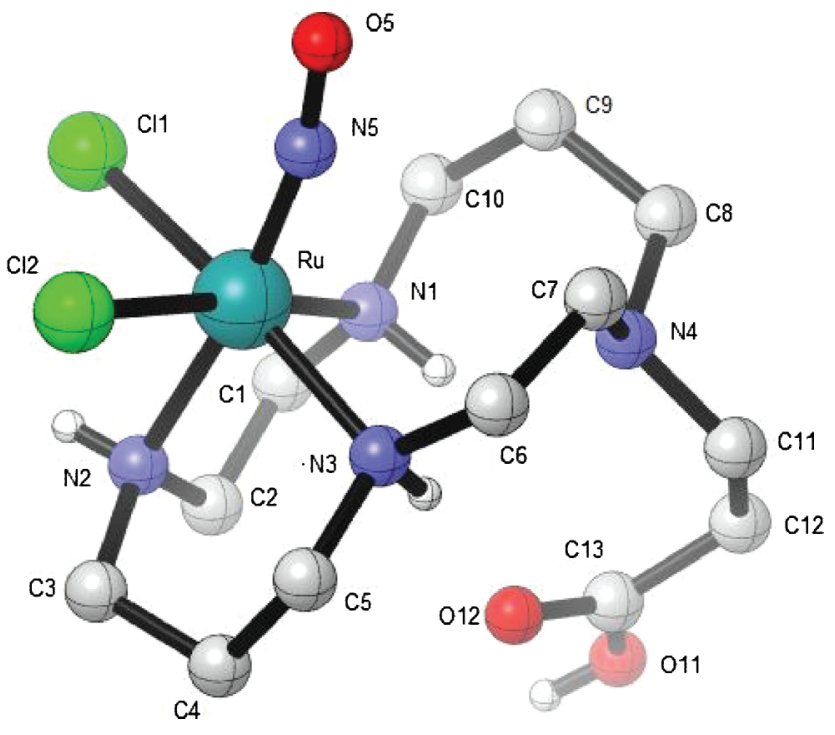

Fig. 6 Structure and numbering of $\mathbf{I}$.

From I to II, the carboxyl group moves towards N1 and N3 by the loss of the O11 proton and the oxygen atoms of this group rotate by $90^{\circ}$. Both movements can be explained by strengthening of the O12-H[N3] and O11-H[N1] hydrogen bonds (Fig. 7a). The changes from I to III are less noticeable, and only the rotation of the carboxyl group is observed (Fig. 7a). After the second deprotonation, the carboxyl group approached the cyclam ring, and there is also a rotation of the $\mathrm{C} 12-\mathrm{C} 11$ bond due to the strengthening of $\mathrm{O} 12-\mathrm{H}[\mathrm{N}(1)]$ and/or $\mathrm{O}(12)-\mathrm{H}[\mathrm{N}(3)]$ hydrogen bonds. It is also possible to observe changes in the cyclam ring, particularly in the neighborhood of $\mathrm{N} 4$ and at the NO group. These results indicate that the second deprotonation changes almost all of the electronic structure of $\mathbf{I}$ (Fig. 7b). The superposition of $\mathbf{V}$ and VII indicates a rotation of the carboxyl group and the movement of this group towards the cyclam ring (Fig. 7c).

A comparison of the bond lengths of $\mathbf{I}$ and the deprotonated species II and III indicates that the largest changes in bond length are observed around the deprotonation site (Table 2). Not only does the $\mathrm{Ru}-\mathrm{N} 3$ distance shorten in III, but the $\mathrm{Ru}-$ Cl1 also lengthen due to the trans effect from the deprotonated N3. Deprotonation at the carboxyl group produces a very strong hydrogen bond, $\mathrm{O} 12-\mathrm{H}[\mathrm{N} 3]$, which in turn results in a significantly increased $\mathrm{N} 3-\mathrm{H}$ distance. This hydrogen bond can be classified as a double charge-assisted hydrogen bond, $( \pm) \mathrm{CAHB}$, which is a strong hydrogen bond. ${ }^{62}$ The shortening of the N3-O11 distance with respect to the sum of van der Waals radii is $26 \%$ which is a significant contraction compared with results presented by Gilli et al. for crystallographic data of organic compounds. ${ }^{63}$ Another hydrogen bond is formed between $\mathrm{O} 12$ and $\mathrm{H}[\mathrm{N} 1]$. In addition, $\mathrm{O} 11-\mathrm{H}[\mathrm{N} 1]$ is strengthened at the expense of the increase in the O11-H[N3] distance. In contrast, III does not present any strong hydrogen bonds. These findings partially explain the larger stability of II compared with III. The changes in the bond lengths for the second deprotonation of II are similar to those observed for the deprotonation of $\mathrm{N} 3$ : the $\mathrm{Ru}-\mathrm{N}_{\text {cyclam }}$ shortens for the $\mathrm{N}$ that was deprotonated. Also, one $\mathrm{Ru}-\mathrm{Cl}$ bond and all $\mathrm{O} 12-\mathrm{H}[\mathrm{N}]$ were lengthened. The $\mathrm{Cl} 2-\mathrm{H}-\mathrm{N} 2$ distance increases, for III, IV, and $\mathbf{V I}$ compared to $\mathbf{I}$. A comparison between $\mathbf{V}$ and the $\mathrm{Ru}-\mathrm{NO}_{2}$ 


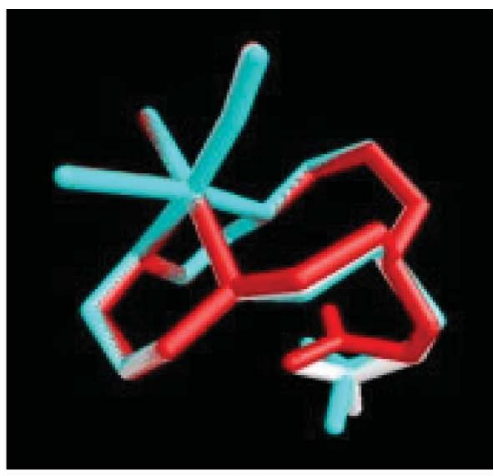

(a)

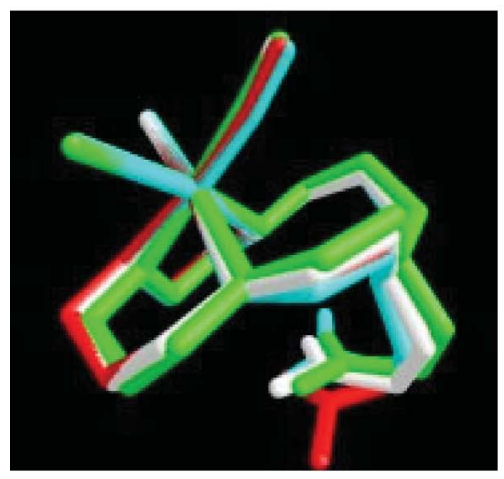

(b)

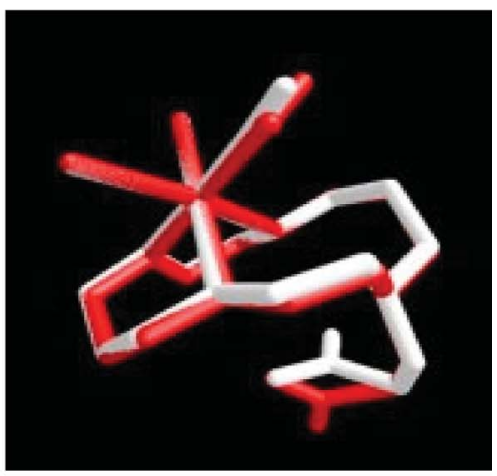

(c)

Fig. 7 Superposition of the deprotonated species of I: (a) I, white; II, red; III, blue. (b) II, white; IV, red; V, blue; VI, green. (c) V, white; VII, red. The molecules were superposed by $\mathrm{Ru} 1, \mathrm{Cl} 1$, and $\mathrm{Cl} 2$. The orientation is the same as in Fig. 6: chlorines are in the upper left and NO in the upper right. The hydrogen atoms have been omitted for clarity.

dianion, VII, indicates an enlargement of the $\mathrm{Ru}-\mathrm{N}$ and of the $\mathrm{N}-\mathrm{O}$ bonds, and an increase in $\mathrm{Ru}-\mathrm{N} 1$ and $\mathrm{Ru}-\mathrm{N} 3$ bond lengths, as expected. Also, all hydrogen bond distances increase.

It was possible to see that the NO bond length of $\mathrm{NO}$ agreed with those calculated for $\mathbf{I}-\mathbf{I V}$ from calculations of NO interatomic distances using the B3LYP, cc-pVDZ model for the isolated $\mathrm{NO}^{+}, \mathrm{NO}$, and $\mathrm{NO}^{-}$, which were $1.068,1.154,1,241 \AA$, respectively (Table 2). These results indicate that the canonical form $\left[\mathrm{Ru}^{\mathrm{III}} \mathrm{NO}\right]$ may have contributed significantly to complex I, as reported for some other $\mathrm{Ru}-\mathrm{NO}$ compounds, ${ }^{37}$ and are in agreement with the $\mathrm{p} K_{\mathrm{a}}$ values of the coordinated water for trans$\left[\mathrm{Ru}(\mathrm{NO})\left(\mathrm{NH}_{3}\right)_{4}\left(\mathrm{OH}_{2}\right)\right]^{3+}$ and trans-[Ru(NO)(salen) $\left.\left(\mathrm{OH}_{2}\right)\right]^{+} .48,49$

The $\mathrm{Ru}-\mathrm{NO}$ bond angle for $\mathrm{I}$ is approximately $10^{\circ}$ off the linearity (Table SI $2 \dagger$ ), while Caramori and Frenking reported calculated $\mathrm{Ru}-\mathrm{N}-\mathrm{O}$ bond angles of $179.1^{\circ}, 179.9^{\circ}$ and $180.0^{\circ}$ for trans-[Ru(NO) $\left.\left(\mathrm{NH}_{3}\right)_{4}(\mathrm{~L})\right]^{\mathrm{n}+}\left(\mathrm{L}=\mathrm{NH}_{3}, \mathrm{Cl}^{-}, \mathrm{H}_{2} \mathrm{O}\right),{ }^{39}$ and Ford and collaborators reported $176.9^{\circ}$ as the $\mathrm{Ru}-\mathrm{N}-\mathrm{O}$ bond angle for $\left[\mathrm{Ru}(\mathrm{NO})\left(\mathrm{NH}_{3}\right)_{5}\right]^{3+}$, using the B3LYP density functional and the $3-21 \mathrm{G}$ basis set, for an experimental value of $172.8^{\circ} .^{35}$ The data for I suggests that the electronic structure of this molecule may be a contribution from two canonical forms: the linear $\left[\mathrm{Ru}^{\mathrm{II}} \mathrm{NO}^{+}\right]$and the bent $\left[\mathrm{Ru}^{\mathrm{III}} \mathrm{NO}\right]$. However it is important to remember that the use of the structure/oxidation state correlations is sometimes problematic, as recently discussed ${ }^{64}$ The first and second deprotonation steps do not cause any significant changes in bond angles. The same is observed for the loss of the second proton. The only exception is $\mathbf{V}$, which presents several significant changes not only in the bond angles in which $\mathrm{N} 2$ is involved. These findings indicate that the structure of $\mathbf{V}$ presents the largest changes around ruthenium compared with all the other deprotonated forms studied in this work.

The calculated vibrational wavenumbers of I compare very well with the experimental values obtained, and the deviations are less than $6 \%$ (Table 3). The deprotonated and dideprotonated species, II-VII, present smaller N5-O5 stretching wavenumbers, compared to $\mathbf{I}$. In contrast, $v(\mathrm{Ru}-\mathrm{N} 5)$ hardly changes with deprotonation. The largest changes in the stretching frequencies are observed in $\mathbf{V}$, compared to II, and this is consistent with the larger geometric changes. With the carboxyl deprotonation of $\mathbf{I}$, it is possible to observe a very large decrease in the $\mathrm{N} 3-\mathrm{H}$ stretching wavenumber in II, reinforcing the observation that the $\mathrm{N} 3-\mathrm{H}-\mathrm{C}=\mathrm{O}$ hydrogen bond is a very strong bond. Compared to $\mathbf{I}$, that vibrational energy decreases for all the other deprotonated and di-deprotonated complexes, but not very strongly; these results indicate that a hydrogen bond is present in III-VI, but it is not as strong as in II. The $v(\mathrm{Ru}-\mathrm{Cl})$ values decrease for all the deprotonated complexes, indicating that there is a redistribution of electronic density after the proton loss, which affects the ruthenium and the atoms linked to it.

Table 4 presents the NPA atomic charges. For I, the Ru charge is three times larger than that for NO, suggesting that the oxidation state of the metal is III. With the first deprotonation, the ruthenium charge becomes slightly more positive, the NO becomes less positive, and the chloro ligands are more negative compared to I, which is consistent with the IR data. As a result, the electron density of the RuNO group is almost constant and $\mathrm{RuNOCl}_{2}$ positive charge decreases from I to II or from I to III. With the second deprotonation, the largest changes in Ru charge take place in $\mathbf{V I}$, which loses 0.568 electron, probably because the $\mathrm{N} 3-\mathrm{H}-\mathrm{O} 12$ very strong hydrogen bond, present in II is lost in VI. Additionally, there is a strong repulsion between the negative carboxylate group with $\mathrm{N} 3$, also negative. In contrast, there is a strong decrease in the NO charge with the deprotonation of N3 (VI) and an increase in the NO charge in VII. As a consequence, the RuNO charge is only 0.500 electron for VI. Changes in the $\mathrm{Cl} 1$ and $\mathrm{Cl} 2$ summed up charges are much less accentuated. The electron density of the $\mathrm{RuNOCl}_{2}$ group increases with the second deprotonation; the largest effect is detected for VI and the smallest for IV. In addition, the electron density of cyclam and the 1-carboxypropyl 
Table 2 Bond lengths for (I)-(VII), Å, for the geometry optimization in vacuum

\begin{tabular}{|c|c|c|c|c|c|c|c|c|}
\hline & & (I) & (II) & (III) & (IV) & $(\mathbf{V})$ & (VI) & (VII) \\
\hline & $(\text { Exp. })^{a}$ & (Calc.) & & & & & & \\
\hline $\mathrm{Ru}-\mathrm{N} 2$ & $2.111(2)$ & 2.170 & 2.163 & 2.181 & 2.175 & 1.979 & 2.179 & 1.979 \\
\hline $\mathrm{Ru}-\mathrm{N} 1$ & $2.133(2)$ & 2.190 & 2.172 & 2.187 & 2.095 & 2.171 & 2.167 & 2.209 \\
\hline Ru-N3 & $2.146(2)$ & 2.211 & 2.187 & 2.098 & 2.194 & 2.226 & 2.086 & 2.272 \\
\hline $\mathrm{Ru}-\mathrm{Cl} 1$ & $2.3789(7)$ & 2.391 & 2.416 & 2.485 & 2.433 & 2.459 & 2.509 & 2.457 \\
\hline $\mathrm{O} 11-\mathrm{H}[\mathrm{N} 1]$ & & 2.488 & 2.249 & 2.701 & - & 2.337 & 2.794 & 2.480 \\
\hline $\mathrm{O} 11-\mathrm{H}[\mathrm{N} 3]$ & & 2.057 & 3.375 & - & 3.415 & - & - & 1.927 \\
\hline $\mathrm{C} 11-\mathrm{H}-\mathrm{N} 2$ & & 2.498 & 2.511 & 2.482 & 2.516 & - & 2.500 & - \\
\hline $\mathrm{Cl} 2-\mathrm{H}-\mathrm{N} 2$ & & 3.200 & 3.213 & 3.252 & 3.333 & - & 3.303 & - \\
\hline $\mathrm{O} 12-\mathrm{H}[\mathrm{N} 1]$ & & 4.202 & 2.353 & 3.768 & - & 2.406 & 2.701 & 4.107 \\
\hline $\mathrm{O} 12-\mathrm{H}[\mathrm{N} 3]$ & & 4.260 & 1.722 & - & 1.779 & 1.835 & - & 4.172 \\
\hline
\end{tabular}

Table 3 Vibrations of I-VII, $\mathrm{cm}^{-1}$, calculated in vacuum

\begin{tabular}{|c|c|c|c|c|c|c|c|c|}
\hline & (I) & & (II) & (III) & (IV) & $(\mathbf{V})$ & (VI) & (VII) \\
\hline $\mathrm{N} 1-\mathrm{H}[\mathrm{N} 1]$ & 3200 & 3339 & 3399 & 3313 & - & 3427 & 3415 & 3368 \\
\hline $\mathrm{N} 2-\mathrm{H}[\mathrm{N} 2]$ & 3200 & 3405 & 3415 & 3408 & 3417 & - & 3233 & - \\
\hline N3-H[N3] & 3200 & 3364 & 2938 & - & 3040 & 3117 & - & 3244 \\
\hline $\mathrm{C}-\mathrm{H}$ & & $3165-2965$ & 3194-2918 & $3162-2902$ & $3144-2829$ & $3176-2871$ & $3130-2852$ & $3198-2819$ \\
\hline
\end{tabular}

Table 4 NPA charges, calculated in vacuum

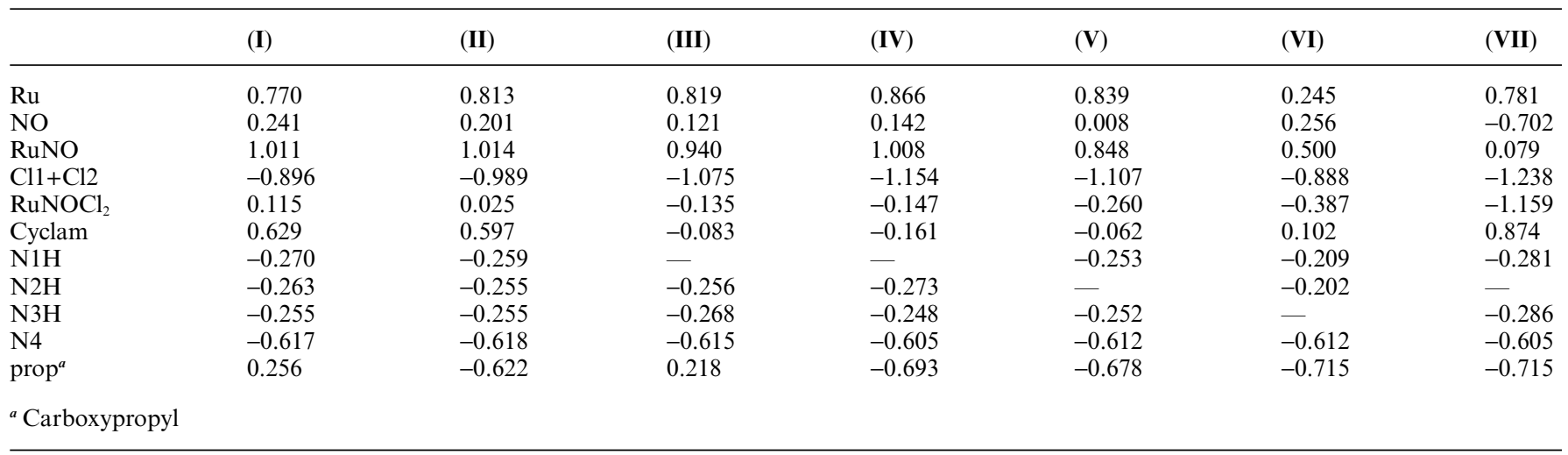

groups decreases with the first and second deprotonation steps. The charges of the NH groups are almost constant with changes in the protonation states of $\mathbf{I}$. The $\mathrm{Ru}$ and cyclam positive charge increases from VI to VII, which is similar to I; NO and both $\mathrm{Cl}$ ligands present high electron density. All of these observations reinforce the conclusion that changes in the protonation state and at the site of deprotonation affect the electron distribution of all atoms of $\mathbf{I}$. These results indicate that varying the $\mathrm{pH}$ of the solution make it possible to modulate the electron distribution in I. Interestingly, the charge decrease shown by the NPA charge calculations for the RuNO groups of $\mathbf{V}$ and $\mathbf{V I}$ is in agreement with the expected negative shifts observed in the redox potentials assigned to $\{\mathrm{RuNO}\}^{6}$ with $\mathrm{pH}$ increase. This observation rules out the formation of IV because the RuNO charge becomes constant.

Wiberg bond indexes, (b.i.), which are related to bond order, are listed in Table 5. It is not possible to conclude whether the most important canonical structure for $\mathbf{I}$ is $\left[\mathrm{Ru}^{\mathrm{III}} \mathrm{NO}\right]$ or $\left[\mathrm{Ru}^{\mathrm{IV}} \mathrm{NO}^{-}\right]$by comparing the b.i. for $\mathrm{NO}$ in $\mathbf{I}$ (1.916) with this index for the isolated $\mathrm{NO}^{-}, \mathrm{NO}$, and $\mathrm{NO}^{+}(2.005,2.100$ and 2.802, respectively) due to the close b.i. of $\mathrm{NO}^{-}$and NO. As stated in the discussion of bond angles, two canonical structures, $\left[\mathrm{Ru}^{\mathrm{III}} \mathrm{NO}\right]$ or $\left[\mathrm{Ru}^{\mathrm{II}} \mathrm{NO}^{+}\right]$, probably contribute largely to $\mathbf{I}$ in contrast with the conclusions 
Table 5 Wiberg bond indexes for I-VII, calculated in vacuum

\begin{tabular}{|c|c|c|c|c|c|c|c|}
\hline & (I) & (II) & (III) & (IV) & $(\mathbf{V})$ & (VI) & (VII) \\
\hline $\mathrm{Ru}-\mathrm{N} 5$ & 1.425 & 1.455 & 1.495 & 1.522 & 1.352 & 1.657 & 0.425 \\
\hline $\mathrm{Ru}-\mathrm{N} 2$ & 0.347 & 0.351 & 0.324 & 0.322 & 0.581 & 0.450 & 0.659 \\
\hline $\mathrm{Ru}-\mathrm{N} 1$ & 0.355 & 0.390 & 0.565 & 0.566 & 0.386 & 0.516 & 0.335 \\
\hline $\mathrm{Ru}-\mathrm{N} 3$ & 0.354 & 0.390 & 0.359 & 0.384 & 0.360 & 0.714 & 0.317 \\
\hline $\mathrm{Ru}-\mathrm{Cll}$ & 0.561 & 0.518 & 0.397 & 0.494 & 0.502 & 0.633 & 0.494 \\
\hline $\mathrm{Ru}-\mathrm{Cl} 2$ & 0.567 & 0.524 & 0.532 & 0.383 & 0.481 & 0.733 & 0.455 \\
\hline $\mathrm{O}(5)-\mathrm{N} 5$ & 1.916 & 1.880 & 1.821 & 1.818 & 1.770 & 1.836 & 1.492 \\
\hline $\mathrm{O}(11)-\mathrm{H}[\mathrm{N} 1]$ & 0.009 & 0.018 & 0.008 & - & 0.695 & 0.004 & 0.000 \\
\hline $\mathrm{O}(11)-\mathrm{H}[\mathrm{N} 3]$ & 0.034 & 0.000 & - & 0.002 & 0.014 & - & 0.056 \\
\hline $\mathrm{Cl}(1)-\mathrm{H}-[\mathrm{N} 2]$ & 0.005 & 0.009 & 0.000 & - & 0.005 & 0.008 & 0.000 \\
\hline $\mathrm{Cl}(2)-\mathrm{H}-[\mathrm{N} 2]$ & 0.002 & 0.000 & - & 0.078 & 0.071 & - & 0.003 \\
\hline N3-H & 0.712 & 0.616 & - & 0.614 & 0.655 & - & 0.678 \\
\hline
\end{tabular}

about b.i; this finding is consistent with Pauling's electroneutrality principle from which the $\left[\mathrm{Ru}^{\mathrm{IV}} \mathrm{NO}^{-}\right]$is less likely. This result shows that further studies will be necessary to clarify the weight of the different canonical structures, $\left[\mathrm{Ru}^{\mathrm{II}} \mathrm{NO}^{+}\right],\left[\mathrm{Ru}^{\mathrm{III}} \mathrm{NO}\right]$, and $\left[\mathrm{Ru}^{\mathrm{IV}} \mathrm{NO}^{-}\right]$in the $\mathrm{Ru}-\mathrm{NO}$ core. All changes in those indexes are consistent with changes in bond lengths. The $\mathrm{Ru}-\mathrm{N} 5$ b.i. increases with the first protonation and the N5-O5 bond length decreases. For III, it is also possible to observe a decrease in the $\mathrm{Ru}-\mathrm{Cl}$ b.i., indicating a redistribution of the electronic density after the deprotonation in N3. Similar to the loss of the first proton, the second deprotonation causes changes in distinct parts of the molecule, which is sometimes far from the deprotonation site. For example, in VI it is possible to observe changes in the b.i. of the carboxylate bonds, which can be attributed to modifications in the hydrogen bonds that involve O11 and O12. VI is the compound where the b.i. changes the most with the second deprotonation, and this can be ascribed to the loss of $\mathrm{N}-\mathrm{H}-\mathrm{OC}$ hydrogen bond. Bond indexes for all bonds involving ruthenium increase, and the N5-O5 b.i. decreases. This decrease is also observed for all the other deprotonated species. In contrast, the Ru-N5 b.i. increases for $\mathbf{I V}$, decreases for $\mathbf{V}$, and the other $\mathrm{Ru}-\mathrm{N}$ and $\mathrm{Ru}-\mathrm{Cl}$ b.i. change or remain constant depending on the deprotonation site. Large decreases in $\mathrm{Ru}-\mathrm{N} 5$ and in O5-N5 are observed from VI to VII, which is consistent with the change from $\mathrm{NO}$ to $\mathrm{NO}_{2}$. Also, it is possible to observe changes in the b.i. for the hydrogen bonds, which is consistent with the bond length and conformational changes.

The analysis of the energies in vacuum or in water (Table 6) indicates that the first deprotonation occurs in the carboxyl group, II. The deprotonation at N3, III, is approximately $10 \mathrm{kcal}^{*} \mathrm{~mol}^{-1}$ less stable compared to the $\mathrm{COOH}$ group, and it is too unstable to be observed in standard conditions. After the second deprotonation, the only species observed in vacuum or in aqueous solution is $\mathbf{V}$ because IV and VI have very high relative Gibbs energies.

\section{Conclusions}

The chemical reactivity and the photolability of the coordinated $\mathrm{NO}$ of the $f a c-\left[\mathrm{Ru}(\mathrm{NO}) \mathrm{Cl}_{2}\left(\kappa^{3} \mathrm{~N}^{4}, \mathrm{~N}^{8}, \mathrm{~N}^{11}\right.\right.$ (1-carboxypropyl)cyclam) $] \mathrm{Cl} \cdot \mathrm{H}_{2} \mathrm{O}$ (I) complex were investigated. Although this complex has a very different architecture compared to analogous complexes, such as trans-[Ru(NO)Cl(cyclam)]( $\left.\mathrm{PF}_{6}\right)_{2}$, due to the $\kappa^{3}$ coordination mode of the substituted cyclic amine which results in fac configuration, the chloride inertness in $\mathbf{I}$ is similar to that observed in the trans analogous complexes. The two chloride ligands do not undergo aquation reactions at room temperature possibly due to $\mathrm{Cl} \cdots \mathrm{H}-\mathrm{N}$ interatomic distances, which are in the range of van der Waals radii for $\mathrm{H}$ and $\mathrm{Cl}$. Complex I also undergoes $\mathrm{OH}^{-}$reversible reactions and $3 \mathrm{pKa}$ values were determined.

The presence of the coordinated $\mathrm{NO}$ in the $f a c-[\mathrm{Ru}(\mathrm{NO})$ $\mathrm{Cl}_{2}\left(\kappa^{3} \mathrm{~N}^{4}, \mathrm{~N}^{8}, \mathrm{~N}^{11}\right.$ (1-carboxypropyl)cyclam)]Cl. $\mathrm{H}_{2} \mathrm{O}$ makes this complex a potential nitric oxide donor because under chemical and electrochemical reductions it is able to release $\mathrm{NO}$ at a rate similar to that of the fastest ruthenium tetraammine analogue reported thus far. Under irradiation with light of 350 or $520 \mathrm{~nm}$, I is also able to release $\mathrm{NO}$ and promote reductive nitrosylation of myoglobin.

Molecular quantum mechanical calculations were made to clarify the structural changes that $\mathbf{I}$ undergoes in each step of the observed acid-base equilibria, and to determine what is

Table 6 Enthalpies, Gibbs energies (Hartree), and relative enthalpies and Gibbs energies $(\mathrm{kcal} / \mathrm{mol})$ for I-VII, calculated without or with a cavity of water

\begin{tabular}{|c|c|c|c|c|c|c|}
\hline & \multicolumn{4}{|l|}{ Vacuum } & \multicolumn{2}{|l|}{ Water } \\
\hline (I) & -2026.32055 & & -2026.39964 & & -2026.78464 & \\
\hline (II) & -2025.92750 & 0.00 & -2026.00498 & 0.00 & -2026.39611 & 0.00 \\
\hline (III) & -2025.90993 & 11.02 & -2025.98979 & 9.54 & -2026.37777 & 11.51 \\
\hline (IV) & -2025.39213 & 9.73 & -2025.46984 & 8.83 & -2025.90317 & 7.55 \\
\hline (V) & -2025.40763 & 0.00 & -2025.48391 & 0.00 & -2025.91521 & 0.00 \\
\hline
\end{tabular}


the most favourable site for the second deprotonation. Among the computational models tested in the theoretical calculations, B3LYP/ECP28MDF,cc-pVDZ resulted in the smallest errors for the experimental geometry of $\mathbf{I}$. Calculations of energies in vacuum and in water indicated that the first deprotonation should occur at the carboxypropyl group and the second deprotonation at N2. A superposition of structures of different species and the comparison of geometric parameters indicate that complex changes occur after the first and second deprotonation steps, which affects the whole molecule. The carboxypropyl deprotonated species, II, presents a very strong $\mathrm{N}-\mathrm{H}-\mathrm{O}$ resonance assisted hydrogen bond, which stabilises this compound. The calculated NO bond length and the $\mathrm{Ru} / \mathrm{NO}$ charge ratio indicate that the predominant canonical structure is $\left[\mathrm{Ru}^{\mathrm{III}} \mathrm{NO}\right]$, but $\mathrm{Ru}-\mathrm{NO}$ bond angles and b.i. provide a less clear picture; bond angles suggest that $\left[\mathrm{Ru}^{\mathrm{II}} \mathrm{NO}^{+}\right]$can contribute to the electronic structure of $\mathbf{I}$ and b.i. indicate a contribution from $\left[\mathrm{Ru}^{\mathrm{IV}} \mathrm{NO}^{-}\right]$. Taking into consideration that some experimental data are consistent with a $\left[\mathrm{Ru}^{\mathrm{II}} \mathrm{NO}^{+}\right]$description and others are in agreement with $\left[\mathrm{Ru}^{\text {III }} \mathrm{NO}\right]$, the best description for I would be a linear combination of the three canonical forms, with a higher weight for $\left[\mathrm{Ru}^{\mathrm{II}} \mathrm{NO}^{+}\right]$and $\left[\mathrm{Ru}^{\mathrm{III}} \mathrm{NO}\right]$. It is clear that further studies with smaller and simpler $\{\mathrm{RuNO}\}^{6}$ complexes will be necessary. All of these data combined with the calculated NPA charges and vibrational frequencies indicate that the first and the second deprotonation steps produce complex changes in the electronic structure of $\mathbf{I}$, not only in the neighborhood of the metal, but also at further regions of the molecule. These findings suggest that the properties of this and other $\mathrm{Ru}-\mathrm{NO}$ complexes can be modified by changing the protonation state.

\section{Experimental}

\section{Materials}

$\mathrm{NaCl}$ (99.99\% purity, Merck) was dried and stored under vacuum prior to use. The oxidised form of myoglobin (horse heart) was obtained from Sigma. All other solvents and reagents were of analytical grade and used as supplied or purified when necessary, according to standard methods. ${ }^{65}$ Commercially available argon (Air Liquide) was passed through a $\mathrm{MnO}_{2}$ column for deoxygenation prior to use in degassing aqueous solutions for photolability studies. All manipulations with air sensitive compounds were conducted following conventional techniques. ${ }^{66}$ Deionised water was used throughout the work.

\section{Preparations}

The free ligand (1-carboxypropyl)cyclam was synthesised and characterised as reported previously. ${ }^{7}$ The (1carboxypropyl)cyclam tetrahydrochloride dihydrate was obtained by dissolving $\sim 0.2 \mathrm{~g}$ of the colourless oil, (1-carboxypropyl)cyclam ligand, in $10 \mathrm{~mL}$ of absolute ethanol followed by the slow addition of $2 \mathrm{~mL}$ of a $6 \mathrm{~mol} \mathrm{~L}^{-1} \mathrm{HCl}$ aqueous solution. The mixture was cooled for $2 \mathrm{~h}$. The white solid was collected by filtration, washed with ethanol, diethylether, and then dried under vacuum. Elemental analysis: $\mathrm{C}, 33.00 ; \mathrm{N}, 7.48 ; \mathrm{H}, 11.97$. Calcd for $\mathrm{C}_{13} \mathrm{H}_{36} \mathrm{O}_{4} \mathrm{~N}_{4} \mathrm{Cl}_{4}: \mathrm{C}, 33.34 ; \mathrm{N}, 7.91 ; \mathrm{H}, 11.21 .{ }^{1} \mathrm{H}$ NMR $(400 \mathrm{MHz}$; $\left.\mathrm{D}_{2} \mathrm{O}\right) \delta_{\mathrm{H}} /$ ppm: $1.99-2.11\left(4 \mathrm{H}, \mathrm{m}, \mathrm{CH}_{2} \mathrm{CH}_{2} \mathrm{CH}_{2}\right), 2.78(2 \mathrm{H}, \mathrm{t}$, $\left.\mathrm{CH}_{2} \mathrm{CO}\right), 3.22-3.33(10 \mathrm{H}, \mathrm{m}), 3.46-3.51(8 \mathrm{H}, \mathrm{m}) .{ }^{13} \mathrm{C}$ NMR $\left(100 \mathrm{MHz} ; \mathrm{D}_{2} \mathrm{O}\right) \delta_{\mathrm{C}} / \mathrm{ppm}: 21.90$ and $22.35\left(\mathrm{CH}_{2} \mathrm{CH}_{2} \mathrm{CH}_{2}\right), 32.17$ $\left(\mathrm{CH}_{2} \mathrm{CO}\right), 40.99,41.57,44.59,44.82,45.24,48.89,48.90,51.82$, $53.10\left(\mathrm{CH}_{2} \mathrm{~N}\right), 177.69(\mathrm{CO})$. IR $v_{\max } / \mathrm{cm}^{-1} 1735(\mathrm{COOH})$.

The $f a c-\left[\mathrm{Ru}(\mathrm{NO}) \mathrm{Cl}_{2}\left(\kappa^{3} \mathrm{~N}^{4}, \mathrm{~N}^{8}, \mathrm{~N}^{11}\right.\right.$ (1-carboxypropyl)cyclam) $] \mathrm{Cl}$. $\mathrm{H}_{2} \mathrm{O}^{7}$ and trans-[Ru(NO)($\left.\left(\mathrm{NH}_{3}\right)_{4}(\mathrm{py})\right]\left(\mathrm{PF}_{6}\right)_{3}{ }^{67}$ complexes were synthesised and characterised as reported.

\section{Physical measurements}

IR spectra were obtained in a Bomem MB 102 FTIR spectrophotometer using $\mathrm{KBr}$ pellets. ${ }^{1} \mathrm{H}$ and ${ }^{13} \mathrm{C}$ NMR spectra were recorded on Bruker Avance DRX400 spectrometer. UV-Vis spectra were acquired in a Hewlett-Packard 8452A or a UV-Vis NIR VarianCary 500 spectrophotometers. Elemental analyses were conducted at the Analytic Central of Chemistry Institute of University of Sao Paulo.

Cyclic voltammetry and differential pulse voltammetry measurements were performed on a Princeton Applied Research (PAR) 273A model potentiostat/galvanostat. All experiments were performed using a conventional three-electrode system. Glassy carbon and platinum gauze were used as working electrodes for cyclic and differential pulse voltammetry, as well as potential controlled electrolysis, respectively. Platinum wire and $\mathrm{Ag} / \mathrm{AgCl}$ electrodes were used as a counter-electrode and reference electrode, respectively. All measurements were conducted in a previously argon degassed aqueous solution. Solution temperatures were maintained using a Haake FK moldel ultracryostat. The reported $E_{1 / 2}^{\prime}$ values were reported the arithmetic mean of $E_{\mathrm{pa}}$ and $E_{\mathrm{pc}}$ values.

NO detection was performed using an NO meter from Innovative Instruments Inc. This apparatus detects $\mathrm{NO}$ directly by means of an amperometric technique.

The rate of NO release $\left(k_{\mathrm{obs}-\mathrm{NO}}\right)$ after electrochemical reduction was estimated with an Autolab PGSTAT 30 (Eco Chemie) bipotentiostat using a platinum microelectrode ${ }^{68}$ (effective radii $15.4 \pm 0.3 \mu \mathrm{m}$ ) as working electrode and $\mathrm{Ag} / \mathrm{AgCl}$ and platinum wire as the reference and counter-electrode, respectively, at $25 \pm$ $1{ }^{\circ} \mathrm{C}$. Scan rates from 0.5 to $40 \mathrm{~V} \mathrm{~s}^{-1}$ were used, and $k_{\text {obs-No }}$ was determined from plots of $\left(E_{\mathrm{pc}}-\mathrm{E}_{1 / 2}\right) v s . \log 1 / \mathrm{v}$, obtained by combination of the equations below.

$$
\begin{gathered}
E_{\mathrm{pc}}=E_{1 / 2}-(R T / \mathrm{n} F) 0.780+(R T / 2 \mathrm{n} F) \ln \lambda \\
\lambda=k R T / \mathrm{n} F \mathrm{~V}
\end{gathered}
$$

\section{$\mathrm{p} K_{\mathrm{a}}$ values}

$\mathrm{p} K_{\mathrm{a}}$ values for (1-carboxypropyl)cyclam tetrahydrochloride and $\mathbf{I}$ were determined by potentiometric titrations. The ionic strength of $2.0 \times 10^{-3} \mathrm{~mol} \mathrm{~L}^{-1}$ (ligand or complex) solutions was adjusted with $0.1 \mathrm{~mol} \mathrm{~L}^{-1} \mathrm{NaCl}$ aqueous solution. Aliquots of a $0.025 \mathrm{~mol} \mathrm{~L}^{-1}$ $\mathrm{NaOH}$ aqueous solution were added using a Metrohm E72 burette at $60 \mathrm{~s}$ time intervals. The increase in $\mathrm{pH}$ was monitored using a digital Analion PM 600 model pHmeter/conductivimeter. All experiments were performed in the dark. Estimations on $\mathrm{p} K_{\mathrm{a}}$ were also performed by running a differential pulse voltammogram experiment after each addition of $\mathrm{NaOH}$ aliquots to a $1.0 \times$ $10^{-3} \mathrm{~mol} \mathrm{~L}^{-1}$ solution of $\mathbf{I}$ in $0.5 \mathrm{~mol} \mathrm{~L}^{-1} \mathrm{HCl}$. 


\section{Chloride lability}

The chloride ligand aquation from I was investigated by potentiometric measurements. A digital Analion PM 600 model pH meter/conductivimeter equipped with an Analion Cl651 model chloride selective and $\mathrm{Ag} / \mathrm{AgCl}$ reference electrode was used. The calibration of selective electrode was performed before each experiment using aqueous $\mathrm{NaCl}$ stock solutions with concentrations in the $5.0 \times 10^{-5}$ to $5.0 \times 10^{-3} \mathrm{~mol} \mathrm{~L}^{-1}$ range and an ionic strength of $0.1 \mathrm{~mol} \mathrm{~L}^{-1} \mathrm{NaNO}_{3}$ and at $\mathrm{pH}$ 3. The temperature of solutions of $\mathbf{I}$ (using the same ionic strength and $\mathrm{pH}$ ) was maintained at 25 or $40 \pm 0.2{ }^{\circ} \mathrm{C}$ using a Haake FK model ultracryostat. The pseudo-first-order rate constant $\left(k_{\text {obs }}\right)$ for $\mathrm{Cl}^{-}$ligand dissociation was determined from the slope of $\ln \left[\mathrm{Cl}^{-}\right] v s$. time at $40{ }^{\circ} \mathrm{C}$. All experiments were performed in the dark.

\section{Photolability of the nitrosyl ligand}

Photolysis experiments for I and trans- $\left[\mathrm{Ru}(\mathrm{NO})\left(\mathrm{NH}_{3}\right)_{4}(\mathrm{py})\right]\left(\mathrm{PF}_{6}\right)_{3}$ (pyNO) $\left(\sim 1.0 \times 10^{-3} \mathrm{~mol} \mathrm{~L}^{-1}\right)$ were performed at $\mathrm{pH} 7.4$ phosphate buffer aqueous solution in a $1.0 \mathrm{~cm}^{-1}$ path length quartz cell capped with a glass reservoir containing $\sim 1 \mathrm{mg}$ of myoglobin (Mb(III)). After degassing for $20 \mathrm{~min}$ with argon, Mb(III) was mixed and dissolved in the solution. Solutions of I (or pyNO) with $\mathrm{Mb}$ (III) were photolysed at $350 \mathrm{~nm}$ in a Rayonet Photochemical Reactor at $25{ }^{\circ} \mathrm{C}$ with constant magnetic stirring, and were monitored spectrophotometrically. For photolysis at $520 \mathrm{~nm}$, a Light Emitting Diode (LED) system with a power of $92 \mathrm{~W} / \mathrm{m}^{2}$ was used. Solutions were photolysed below 5\% of reaction to minimise inner filter effects. No spectral changes were observed for $\mathrm{Mb}$ (III) solutions without I (or pyNO) using the same procedures. Dark reactions were performed simultaneously by using solutions of identical composition. As inferred from their UV-Vis spectra, solutions of ruthenium nitrosyls (I or pyNO), $\mathrm{Mb}(\mathrm{III})$, and $\mathrm{Mb}(\mathrm{III})$ + ruthenium nitrosyls (I or pyNO) were stable at room temperature for at least 1 day.

\section{Computational Methods}

Some computational models were tested for fac-[Ru(NO)$\mathrm{Cl}_{2}\left(\kappa^{3} \mathrm{~N}^{4}, \mathrm{~N}^{8}, \mathrm{~N}^{11}\right.$ (1-carboxypropyl)cyclam) $] \mathrm{Cl} \cdot \mathrm{H}_{2} \mathrm{O}$, as described in ESI $\dagger$; the B3LYP/ECP28MDF, cc-pVDZ model was able to satisfactorily reproduce the experimental geometries. This model was used to calculate the optimisation and vibrational frequencies for all other species. A single point calculation was accomplished by B3LYP/ECP28MDF, aug-cc-pVDZ. The atomic charges were calculated by the NPA method ${ }^{69,70}$ and the bond indexes by the Wiberg method. ${ }^{71}$ All calculations were made in vacuum, except the for the determination of Gibbs energies in water that were conducted by the IEFPCM method. ${ }^{72}$ The superposition of the different structures was conducted by VEGA ZZ 2.3.1 software. $^{73}$ The structure in Fig. 6 was illustrated with the aid of the CYLview software.

\section{Acknowledgements}

The authors thank the Brazilian Agencies CAPES, CNPq, FAPESB and Fapesp for grants and fellowships as well as Professor Alzir A. Batista for use of his laboratory and Cynthia M. C. Prado Manso for revision of the English language.

\section{References}

1 E. Tfouni, K. Q. Ferreira, F. G. Doro, R. S. da Silva and Z. N. da Rocha, Coord. Chem. Rev., 2005, 249, 405.

2 E. Tfouni, M. Krieger, B. R. McGarvey and D. W. Franco, Coord. Chem. Rev., 2003, 236, 57.

3 E. Tfouni, F. G. Doro, A. J. Gomes, R. S. da Silva, G. Metzker, P. G. Z. Benini and D. W. Franco, Coord. Chem. Rev., 2010, 254, 355.

4 E. Tfouni, F. G. Doro, L. E. Figueiredo, J. M. C. Pereira, G. Metzker and D. W. Franco, Curr. Med. Chem., 2010, 17, 3643.

5 R. S. daSilva, M. T. P. Gambardella, R. H. A. Santos, B. E. Mann and E. Tfouni, Inorg. Chim. Acta, 1996, 245, 215.

6 D. R. Lang, J. A. Davis, L. G. F. Lopes, A. A. Ferro, L. C. G. Vasconcellos, D. W. Franco, E. Tfouni, A. Wieraszko and M. J. Clarke, Inorg. Chem., 2000, 39, 2294.

7 F. G. Doro, E. E. Castellano, L. A. B. Moraes, M. N. Eberlin and E. Tfouni, Inorg. Chem., 2008, 47, 4118.

8 K. Q. Ferreira and E. Tfouni, J. Braz. Chem. Soc., 2010, 21, 1349.

9 R. S. daSilva and E. Tfouni, Inorg. Chem., 1992, 31, 3313.

10 K. Q. Ferreira, F. G. Doro and E. Tfouni, Inorg. Chim. Acta, 2003, 355, 205.

11 F. D. Oliveira, K. Q. Ferreira, D. Bonaventura, L. M. Bendhack, A. C. Tedesco, S. D. Machado, E. Tfouni and R. S. da Silva, J. Inorg. Biochem., 2007, 101, 313.

12 M. Silva and E. Tfouni, Inorg. Chem., 1997, 36, 274.

13 K. Q. Ferreira, F. G. Santos, Z. N. da Rocha, T. Guaratini, R. S. da Silva and E. Tfouni, Inorg. Chem. Commun., 2004, 7, 204.

14 D. D. Walker and H. Taube, Inorg. Chem., 1981, 20, 2828.

15 B. F. de Barros, J. C. Toledo, D. W. Franco, E. Tfouni and M. H. Krieger, Nitric Oxide, 2002, 7, 50.

16 P. G. Zanichelli, H. F. G. Estrela, R. C. Spadari-Bratfisch, D. M. GrassiKassisse and D. W. Franco, Nitric Oxide, 2007, 16, 189.

17 A. J. Gomes, P. A. Barbougli, E. M. Espreafico and E. Tfouni, J. Inorg. Biochem., 2008, 102, 757.

18 J. J. J. Silva, A. L. Osakabe, W. R. Pavanelli, J. S. Silva and D. W. Franco, Br. J. Pharmacol., 2007, 152, 112.

19 C. R. Pestana, D. P. S. Phelippin, A. C. M. Polizello, D. J. Dorta, S. A. Uyemura, A. C. Santos, F. G. Doro, F. P. Rodrigues, E. Tfouni and C. Curti, Nitric Oxide, 2009, $20,24$.

20 P. M. M. Guedes, F. S. Oliveira, F. R. S. Gutierrez, G. K. da Silva, G. J. Rodrigues, L. M. Bendhack, D. W. Franco, M. A. D. Matta, D. S. Zamboni, R. S. da Silva and J. S. Silva, Br. J. Pharmacol., 2010, 160, 270 .

21 F. G. Marcondes, A. A. Ferro, A. Souza-Torsoni, M. Sumitani, M. J. Clarke, D. W. Franco, E. Tfouni and M. H. Krieger, Life Sci., 2002, 70, 2735.

22 J. C. M. Pereira, V. Carregaro, D. L. Costa, J. S. da Silva, F. Q. Cunha and D. W. Franco, Eur. J. Med. Chem., 2010, 45, 4180.

23 C. M. de Gaitani, M. C. C. de Melo, C. N. Lunardi, F. D. Oliveira, R. S. da Silva and L. M. Bendhack, Nitric Oxide, 2009, 20, 195.

24 A. G. De Candia, J. P. Marcolongo and L. D. Slep, Polyhedron, 2007, 26, 4719 .

25 K. Q. Ferreira, A. M. Lucchesi, Z. N. da Rocha and R. S. da Silva, Inorg. Chim. Acta, 2002, 328, 147.

26 Z. N. da Rocha, K. Q. Ferreira, M. Silva, E. C. de Oliveira, G. Chiericato and E. Tfouni, Inorg. Chem., 2001, 40, 5385.

27 C. M. Che, S. S. Kwong, C. K. Poon, T. F. Lai and T. C. W. Mak, Inorg. Chem., 1985, 24, 1359.

28 F. S. Oliveira, V. Togniolo, T. Pupo, A. C. Tedesco and R. S. da Silva, Inorg. Chem. Commun., 2004, 7, 160.

29 R. M. Carlos, A. A. Ferro, H. A. S. Silva, M. G. Gomes, S. S. S. Borges, P. C. Ford, E. Tfouni and D. W. Franco, Inorg. Chim. Acta, 2004, 357, 1381.

30 L. J. Ignarro, in Nitric Oxide; Biology and Pathobiology, Academic Press, USA, 2000.

31 D. D. Thomas, L. A. Ridnour, J. S. Isenberg, W. Flores-Santana, C. H. Switzer, S. Donzelli, P. Hussain, C. Vecoli, N. Paolocci, S. Ambs, C. A. Colton, C. C. Harris, D. D. Roberts and D. A. Wink, Free Radical Biol. Med., 2008, 45, 18.

32 D. A. Wink and J. B. Mitchell, Free Radical Biol. Med., 1998, 25, 434.

33 D. A. Wink, Y. Vodovotz, J. A. Cook, M. C. Krishna, S. Kim, D. Coffin, W. DeGraff, A. M. Deluca, J. Liebmann and J. B. Mitchell, Biochemistry Moscow, 1998, 63, 802.

34 P. Pacher, J. S. Beckman and L. Liaudet, Physiol. Rev., 2007, 87, 315. 
35 J. C. Patterson, I. M. Lorkovic and P. C. Ford, Inorg. Chem., 2003, 42, 4902.

36 O. V. Sizova, V. I. Baranovski, N. V. Ivanova and V. V. Sizov, Mol. Phys., 2003, 101, 715.

37 O. Lyubimova, O. V. Sizova, C. Loschen and G. Frenking, Theochem, $2008, \mathbf{8 6 5}, 28$.

38 O. V. Sizova, A. Y. Sokolov, L. V. Skripnikov and V. I. Baranovski, Polyhedron, 2007, 26, 4680.

39 G. F. Caramori and G. Frenking, Organometallics, 2007, 26, 5815.

40 M. J. Rose and P. K. Mascharak, Inorg. Chem., 2009, 48, 6904.

41 P. De, T. K. Mondal, S. M. Mobin, B. Sarkar and G. K. Lahiri, Inorg. Chim. Acta, 2010, 363, 2945.

42 J. H. Enemark and R. D. Feltham, Coord. Chem. Rev., 1974, 13, 339.

43 S. I. Gorelsky and A. B. P. Lever, Int. J. Quantum Chem., 2000, 80, 636.

44 S. I. Gorelsky, S. C. da Silva, A. B. P. Lever and D. W. Franco, Inorg. Chim. Acta, 2000, 300, 698.

45 A. G. De Candia, J. P. Marcolongo, R. Etchenique and L. D. Slep, Inorg. Chem., 2010, 49, 6925.

46 M. Studer and T. A. Kaden, Helv. Chim. Acta, 1986, 69, 2081.

47 R. D. Hancock, R. J. Motekaitis, J. Mashishi, I. Cukrowski, J. H. Reibenspies and A. E. Martell, J. Chem. Soc., Perkin Trans. 2, 1996, 1925.

48 C. W. B. Bezerra, S. C. da Silva, M. T. P. Gambardella, R. H. A. Santos, L. M. A. Plicas, E. Tfouni and D. W. Franco, Inorg. Chem., 1999, 38, 5660.

49 J. Bordini, D. O. Novaes, I. E. Borissevitch, B. T. Owens, P. C. Ford and E. Tfouni, Inorg. Chim. Acta, 2008, 361, 2252.

50 M. G. Gomes, C. U. Davanzo, S. C. Silva, L. G. F. Lopes, P. S. Santos and D. W. Franco, J. Chem. Soc., Dalton Trans., 1998, 601.

51 F. Roncaroli, M. E. Ruggiero, D. W. Franco, G. L. Estiu and J. A. Olabe, Inorg. Chem., 2002, 41, 5760.

52 J. A. Broomhead, F. Basolo and R. G. Pearson, Inorg. Chem., 1964, 3, 826.
53 J. A. Marchant, T. Matsubara and P. C. Ford, Inorg. Chem., 1977, 16, 2160.

54 P. S. Pallavicini, A. Perotti, A. Poggi, B. Seghi and L. Fabbrizzi, J. Am. Chem. Soc., 1987, 109, 5139.

55 A. Schiegg and T. A. Kaden, Helv. Chim. Acta, 1990, 73, 716.

56 E. K. Barefield, Coord. Chem. Rev., 2010, 254, 1607.

57 E. Tfouni, Coord. Chem. Rev., 2000, 196, 281.

58 R. M. Carlos, D. R. Cardoso, E. E. Castellano, R. Z. Osti, A. J. Camargo, L. G. Macedo and D. W. Franco, J. Am. Chem. Soc., 2004, 126, 2546.

59 J. A. McCleverty, Chem. Rev., 2004, 104, 403.

60 M. Hoshino, M. Maeda, R. Konishi, H. Seki and P. C. Ford, J. Am. Chem. Soc., 1996, 118, 5702.

61 M. Hoshino, K. Ozawa, H. Seki and P. C. Ford, J. Am. Chem. Soc., 1993, 115, 9568 .

62 G. Gilli and P. Gilli, J. Mol. Struct., 2000, 552, 1.

63 P. Gilli, L. Pretto, V. Bertolasi and G. Gilli, Acc. Chem. Res., 2009, 42, 33.

64 G. K. Lahiri and W. Kaim, Dalton Trans., 2010, 39, 4471.

65 D. D. Perrin, W. L. F. Armarego and D. R. Perrin, in Purification of Laboratory Chemicals, Pergamon Press Ltd, Oxford. 2nd edn., 1980.

66 D. F. Shriver, in The Manipulation of Air Sensitive Compounds, MacGraw-Hill Co., New York. 1969.

67 S. D. S. Borges, C. U. Davanzo, E. E. Castellano, J. Schpector, S. C. Silva and D. W. Franco, Inorg. Chem., 1998, 37, 2670.

68 V. Mori and M. Bertotti, Analyst, 2000, 125, 1629.

69 A. E. Reed and F. Weinhold, J. Chem. Phys., 1983, 78, 4066

70 A. E. Reed, R. B. Weinstock and F. Weinhold, J. Chem. Phys., 1985, 83, 735 .

71 K. B. Wiberg, Tetrahedron, 1968, 24, 1083.

72 E. Cances, B. Mennucci and J. Tomasi, J. Chem. Phys., 1997, 107, 3032.

73 A. Pedretti, L. Villa and G. Vistoli, J. Mol. Graphics Modell., 2002, 21, 47. 